


\section{Arquitecturas Ambulatorias}

Obradoiro de aprendizaxe-servizo co barrio do Campanario

Cristina Botana

Rocío Botana (coords.) 


\title{
Arquitecturas Ambulatorias
}

Obradoiro de aprendizaxe-servizo co barrio do Campanario

do 18 de setembro ao 25 de outubro

Coordinación e organización

Cristina Botana, Rocío Botana

Publicación

Servizo de Publicacións da UDC

Textos (por intervención): Cristina Botana; Rocío Botana; Ramón Pérez; Carlos Gómez; Iago Carro; Xiao Varela; Alberto Matarán; José Luis Martínez; Luciano G. Alfaya; Patricia Muñiz; Xabi Lombardero;

Cristina Campillo; Sebijan Fezjula; Cayetano Fernández; Michael Juan Sierra; Fernando Pérez; Tiffany López Ganet; Roi Zas; Cathryn Teasley; Rosa Ferández; Carlos Diz; Simón Rodríguez; Plácido Lizancos.

Deseño e maquetación: Fernando Pérez

Fotografía: fontes e autorías no índice de fotografías (p. 55)

Gráficos: Cristina Botana (p.11, 12, 13, 14, 15, 25, 26 e 27); Ergosfera (p. 20 e 21)

Impresión: Global Print

Edita: Universidade da Coruña, Servizo de Publicacións, A Coruña, 2019 $<$ www.udc.gal/publicacions>

\author{
(c) da edición, Universidade da Coruña \\ (c) imaxe de cuberta, Cristina Botana \\ (C) gráfico encartado, Ergosfera \\ (c) dos gráficos, Cristina Botana \\ (C) dos textos, as súas autoras \\ Número de páxinas: 56 \\ $14 ' 8 \times 21 \mathrm{~cm}$ \\ ISBN impresión: 978-84-9749-751-0 \\ ISBN electrónico: 978-84-9749-752-7 \\ DL: C 2065-2019 \\ DOI: https://doi.org/10.17979/spudc.9788497497527 \\ IBIC/Thema: JFF | RPC| AMVD|JKS|1DSEL
}

Reservados todos os dereitos. Nin a totalidade nin parte deste libro pode reproducirse ou transmitirse por ningún procedemento electrónico ou mecánico, incluíndo fotocopia, gravación magnética ou calquera almacenamento de información e sistema de recuperación, sen o permiso previo e por escrito das persoas titulares do copyright.

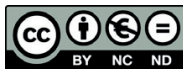

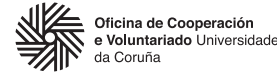

XUNTA DE GALICIA

CONSELLERÍA DE EDUCACIÓN, UNIVERSIDADE F FORMACIÓN PROFFSIONAI
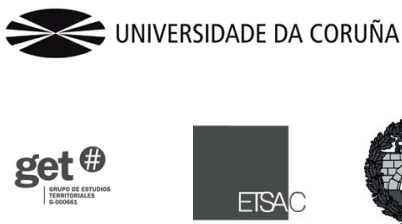

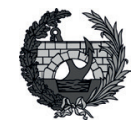




\section{Arquitecturas Ambulatorias}

Cristina Botana | Rocío Botana (coords.)

O Proxecto Arquitecturas Ambulatorias. Obradoiro de aprendizaxe -servizo co barrio do Campanario (A Coruña) foi desenvolvido no marco das accións contempladas na VI Convocatoria de Educación para o Desenvolvemento Sensibilización e Participación Social financiadas pola Oficina de Cooperación e Voluntariado da Universidade da Coruña, durante os meses de setembro e outubro de 2019. 



\section{INTRODUCIÓN}

Esta pequena publicación nace durante as xornadas realizadas no marco do proxecto Arquitecturas Ambulatorias, a través do cal se propuxo un obradoiro de aprendizaxe-servizo no que reunir ao alumnado interesado de diversas áreas formativas como a socioloxía, a enxeñaría, a educación social, a arquitectura, o urbanismo e o traballo social; nun espazo de aprendizaxe colectivo sobre os procesos de construción social do hábitat, as políticas sociais e a racialización dos espazos urbanos.

A premisa que fiaba os obxectivos das xornadas era abordar todas estas cuestións desde unha perspectiva crítica e transdisciplinar como base, no que analizar certas prácticas urbanas como consecuencias non só dun urbanismo deshumanizado ao servizo do capital, senón tamén das estruturas racistas que atravesan o noso sistema social e polo tanto as nosas cidades.

O barrio do Campanario foi o punto de referencia por ser un dos barrios da Coruña marcado historicamente por todas estas cuestións e que novamente se atopa ameazado polos plans de expansión urbanística. Trátase dun barrio de infravivendas promovido pola administración local nos anos 60 para desprazar poboacións empobrecidas das novas centralidades urbanas. Continúa a ser de titularidade municipal a día de hoxe, e a súa veciñanza, composta por poboación paia e xitana, ten unha capacidade de acción e mobilización social moi importantes que ben poden ser chave para ser escoitados e respectados. Un dos obxectivos implícitos neste proxecto é reflexionar sobre estes procesos, sobre as causas e intereses que subxacen, as ferramentas dispoñibles para a poboación e, sobre todo, as potencialidades do barrio como suxeito político de acción cidadá.

O foco destas xornadas non foi a comunidade romaní nin os barrios de infravivendas existentes na nosa cidade, senón que se tratou de ollar cara as institucións que reproducen lóxicas segregadoras, establecendo xerarquías en veciñanzas de primeira e de segunda, expulsando do acceso á cidade e á cidadanía plena e autónoma a todos aqueles sectores da poboación que percibimos como "outros". 
As palestras organizáronse en bloques temáticos que partiron da contextualización inicial na realidade territorial da cidade, pasando pola análise de metodoloxías alternativas para a xestión social do hábitat, até os discursos emancipatorios desde os dereitos colectivos que procuran recoñecer as estruturas racistas para entender a realidade e, deste xeito, atopar respostas reparadoras, comezando por facer as preguntas axeitadas: entender as desigualdades sociais no acceso ao hábitat digno como resultado directo das políticas públicas no urbano e no social; recoñecer a exclusión como consecuencia dun sistema de ordenación social racista que deshumaniza a certas comunidades para xustificar a dominación da sociedade hexemónica; e, por último, entender que o racismo vai mais alá das condutas individuais produto dos prexuízos, que é un principio organizador da modernidade que se materializa nas nosas cidades segregadas e na intervención social baseada no asimilacionismo.

Ao tempo que a cidade medra, as comunidades racializadas e marcadas como diferentes deben diluírse entre a maioría ou desaparecer definitivamente. A nosa forma de construír cidade non deixa lugar á diversidade, pero tampouco ofrece ningunha garantía de acceso ao fogar e ao espazo público. Neste escenario, os servizos sociais funcionan como coidados paliativos que atenúan os danos nas estruturas sociais. 0 urbanismo e os servizos sociais forman así unha perfecta simbiose ao servizo da modernidade, negando a existencia dun sistema caníbal que culpabiliza as comunidades afectadas polos efectos provocados polas propias institucións, e impoñendo solucións fragmentadas que quebran aínda máis os lazos comunitarios de apoio mutuo e resistencia.

A continuación inclúense as voces daquelas persoas que participaron deste espazo, ben como relatoras/es, colaborando e apoiando este proxecto ou ben como escoitantes nas palestras. Entre elas, están as voces da veciñanza do Campanario, que transmiten as súas inquedanzas e nos recordan que son un barrio loitador, que non ficará quedo ante calquera agresión, chegue desde onde chegue. 


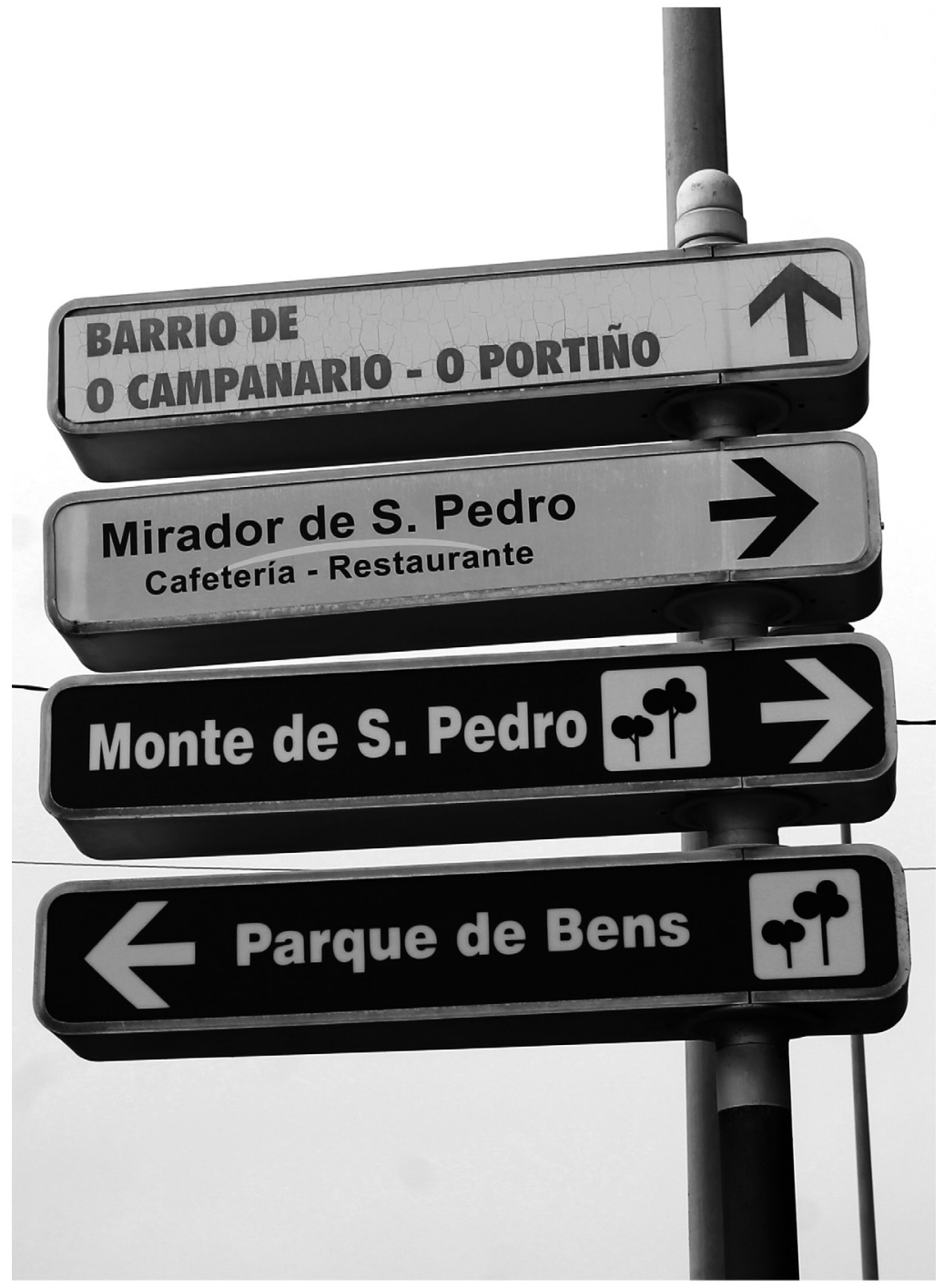


Cogieron a las familias más pobres de la ciudad y nos alejaron del mundo. Nos mandaron lo más lejos posible. Al principio fuimos 5 familias, luego otras 3, así sucesivamente hasta ocupar los primeros 44 barracones que se hicieron. Era un sitio que cuando se cortaba la luz tardaba un mes en que la volvieran a poner, allí sólo había un camino que conducía al puerto. Que, por cierto, es el primer puerto de la ciudad, mucha gente no lo sabe, había también un molino de agua del siglo XVII... Todo eso quedó sepultado cuando cayó el vertedero, igual que el cementerio romano. Es una pena, porque eso es parte de la historia de la ciudad que quedó borrada, pero todo se tapó. Nadie dijo nada ni protestó.

-Ramón Pérez, veciño e anterior presidente da AAVV do Campanario. 


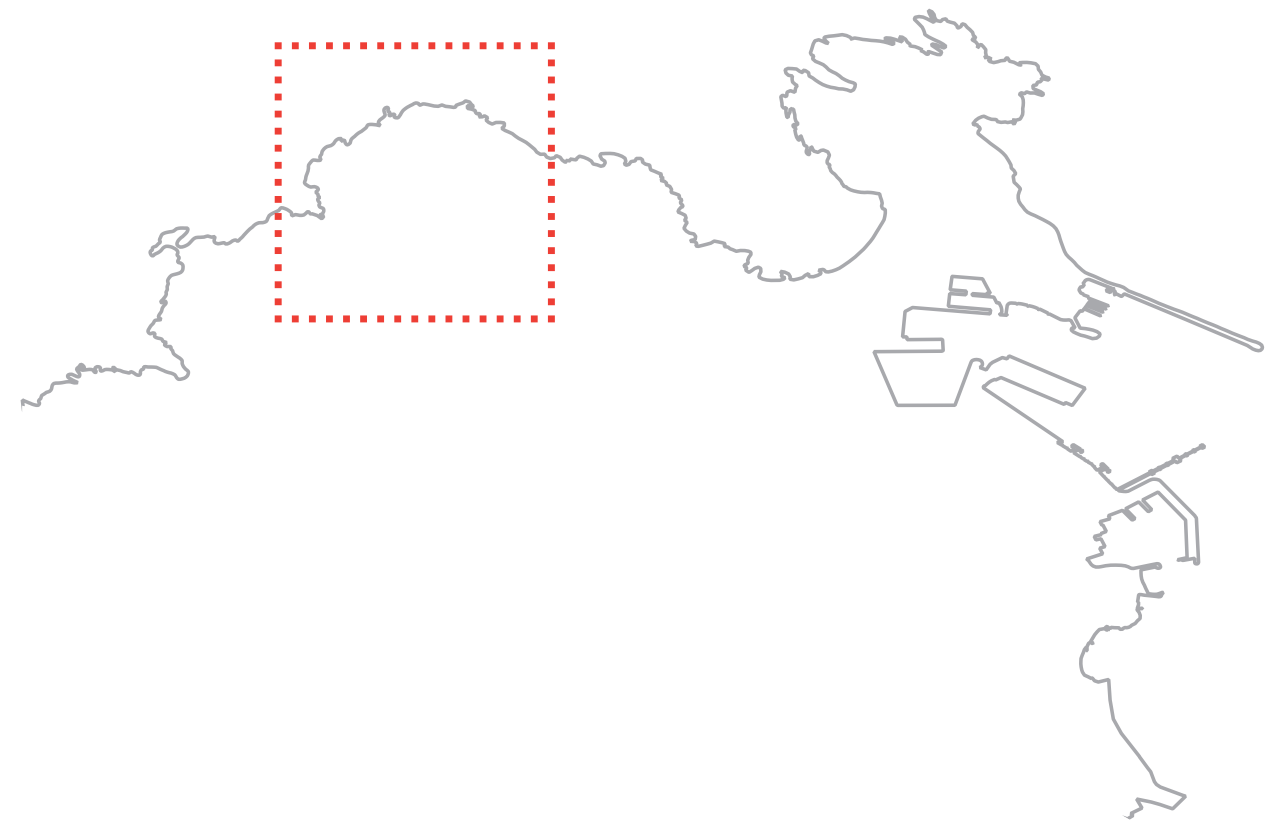

O barrio do Campanario na cidade

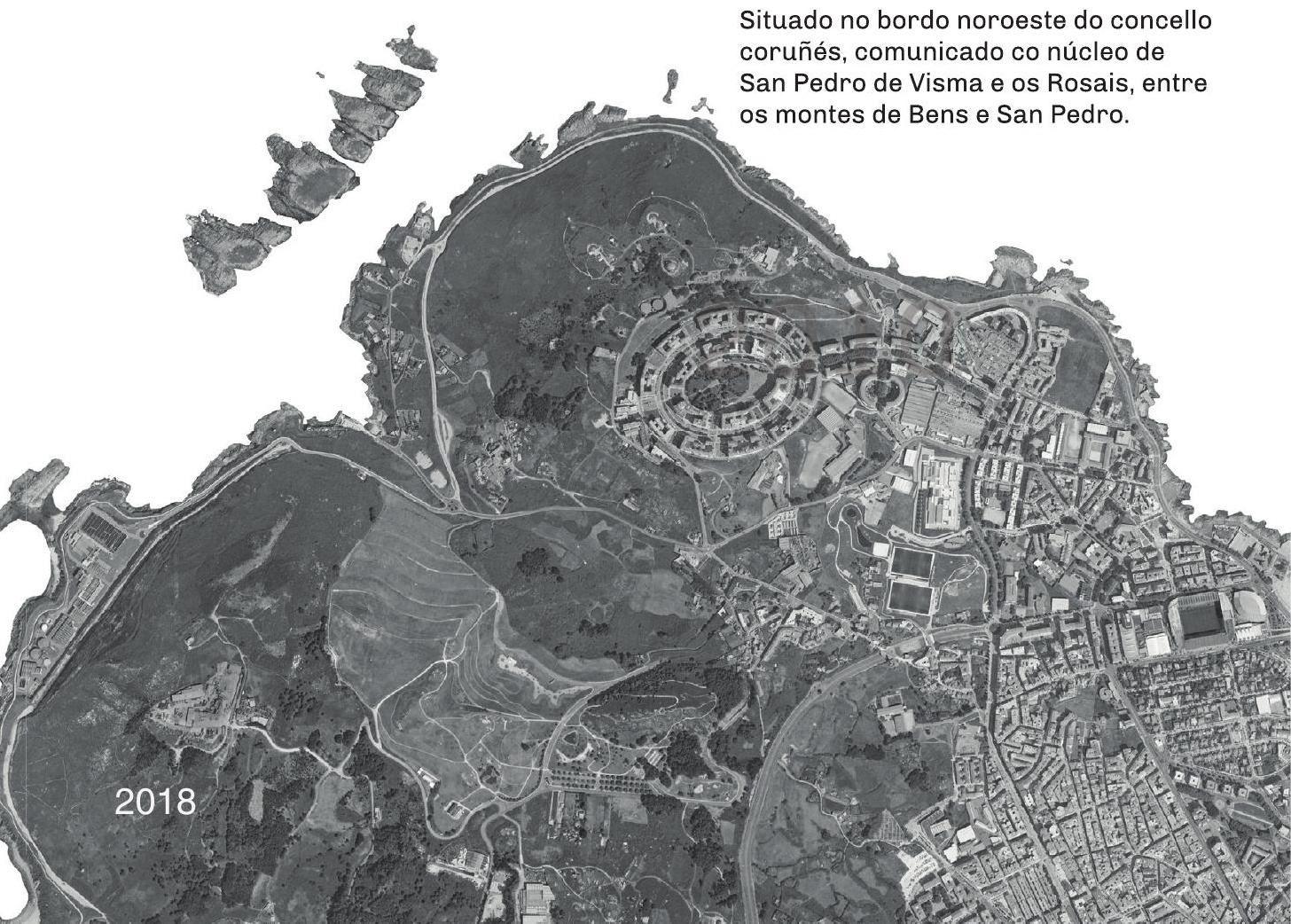


1957
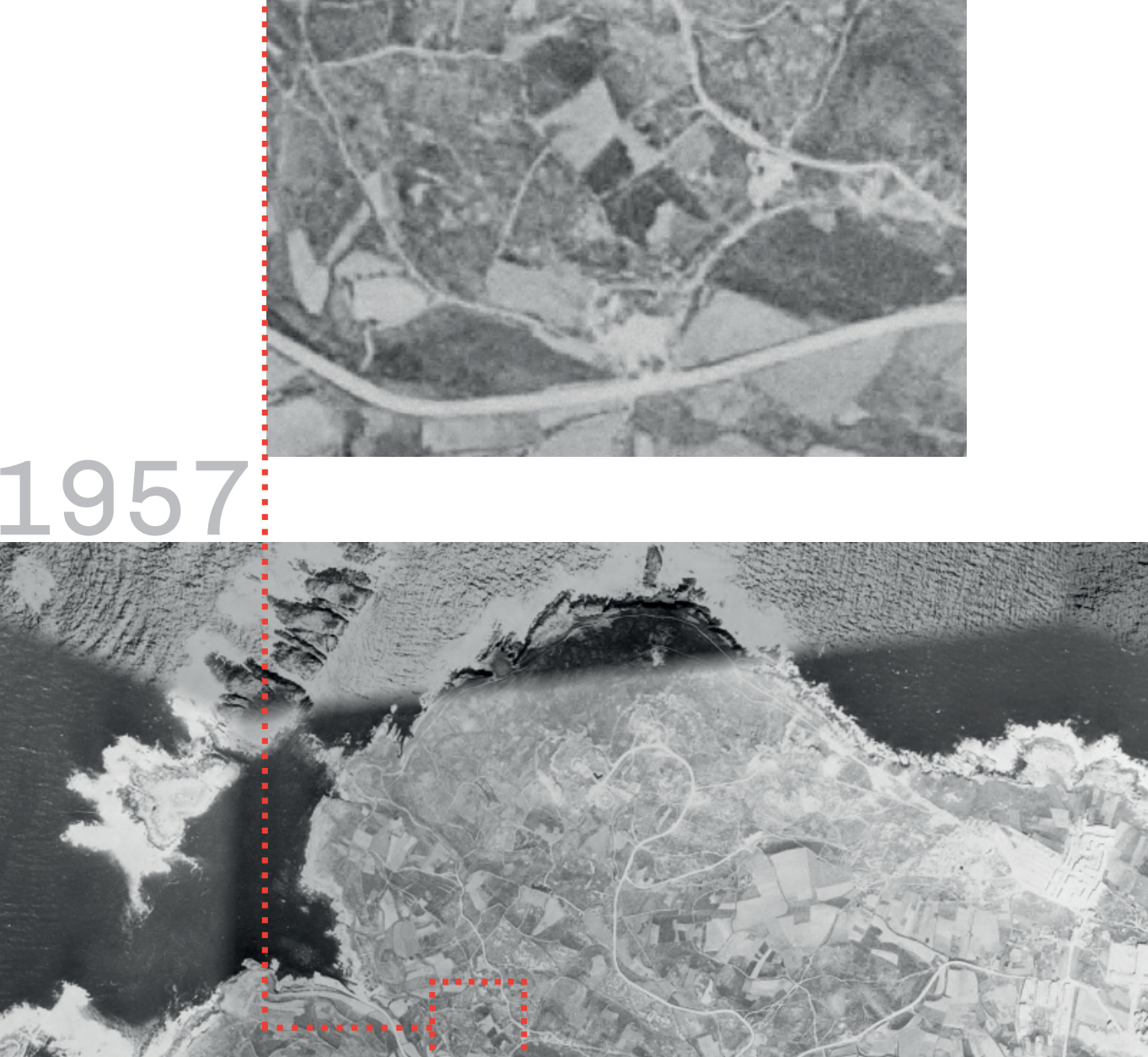

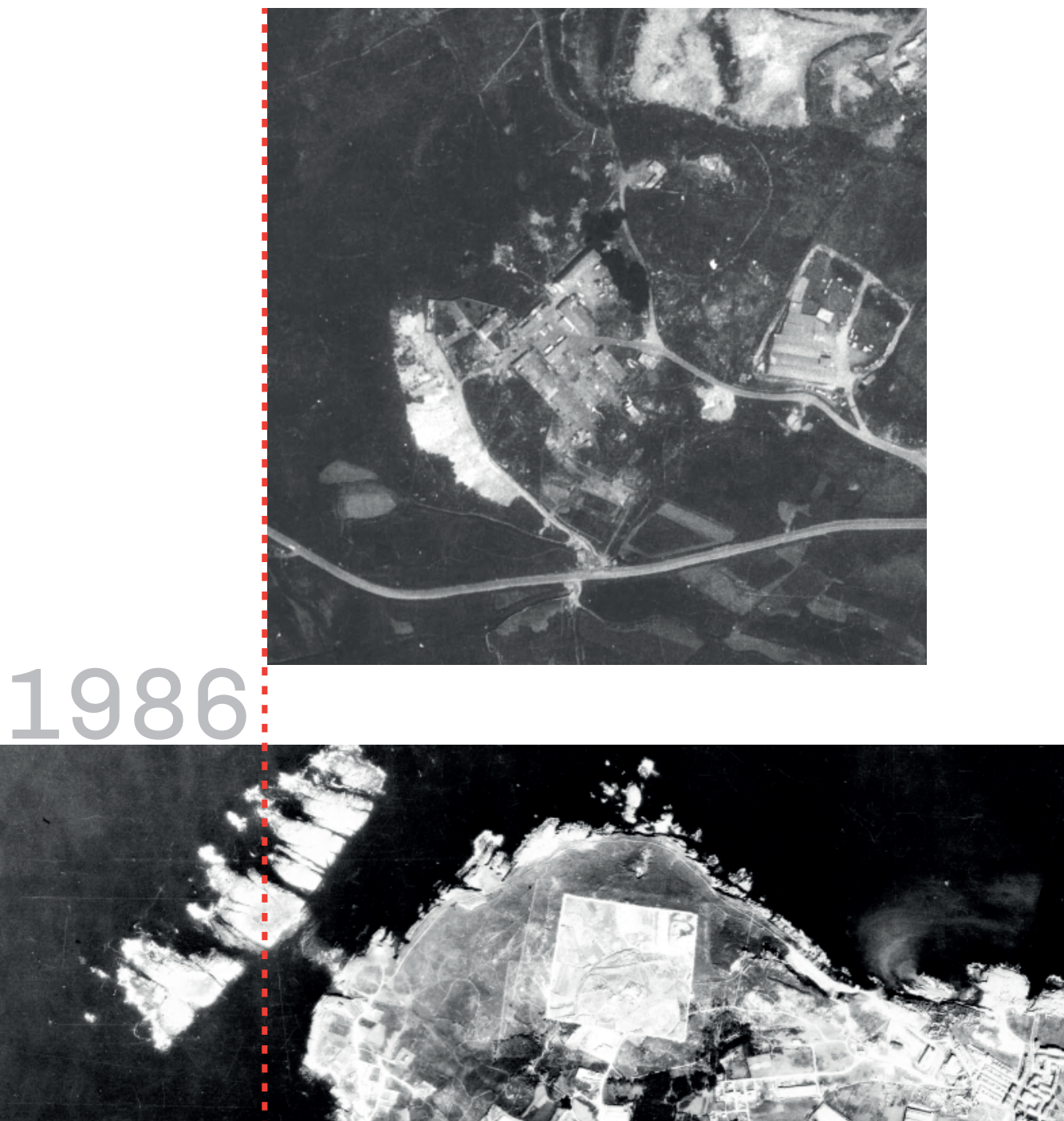

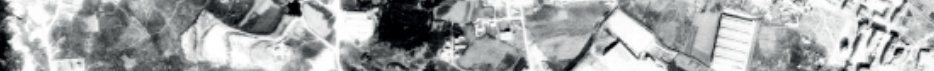
2.

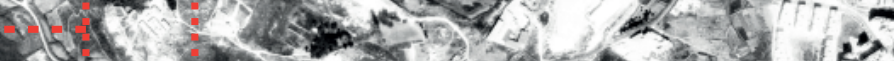

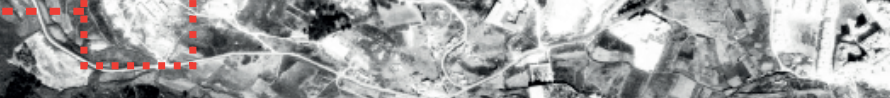

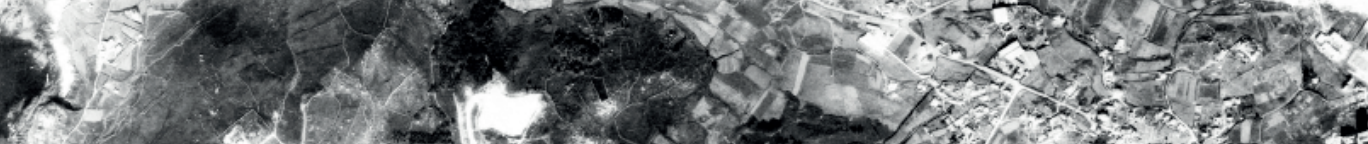

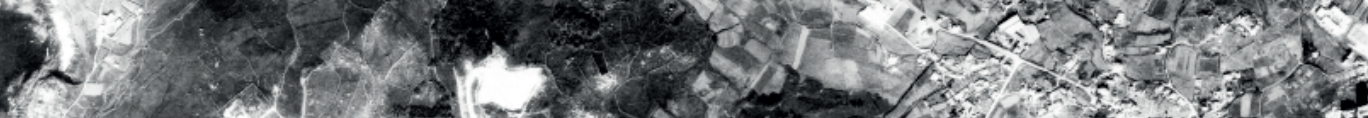

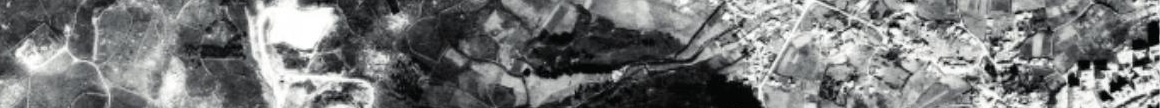

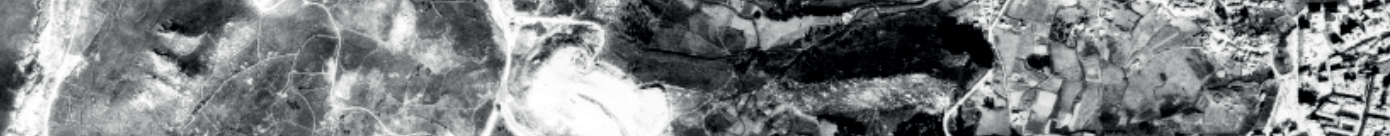
2. 3 ( (1. 2. 7 . 3. 

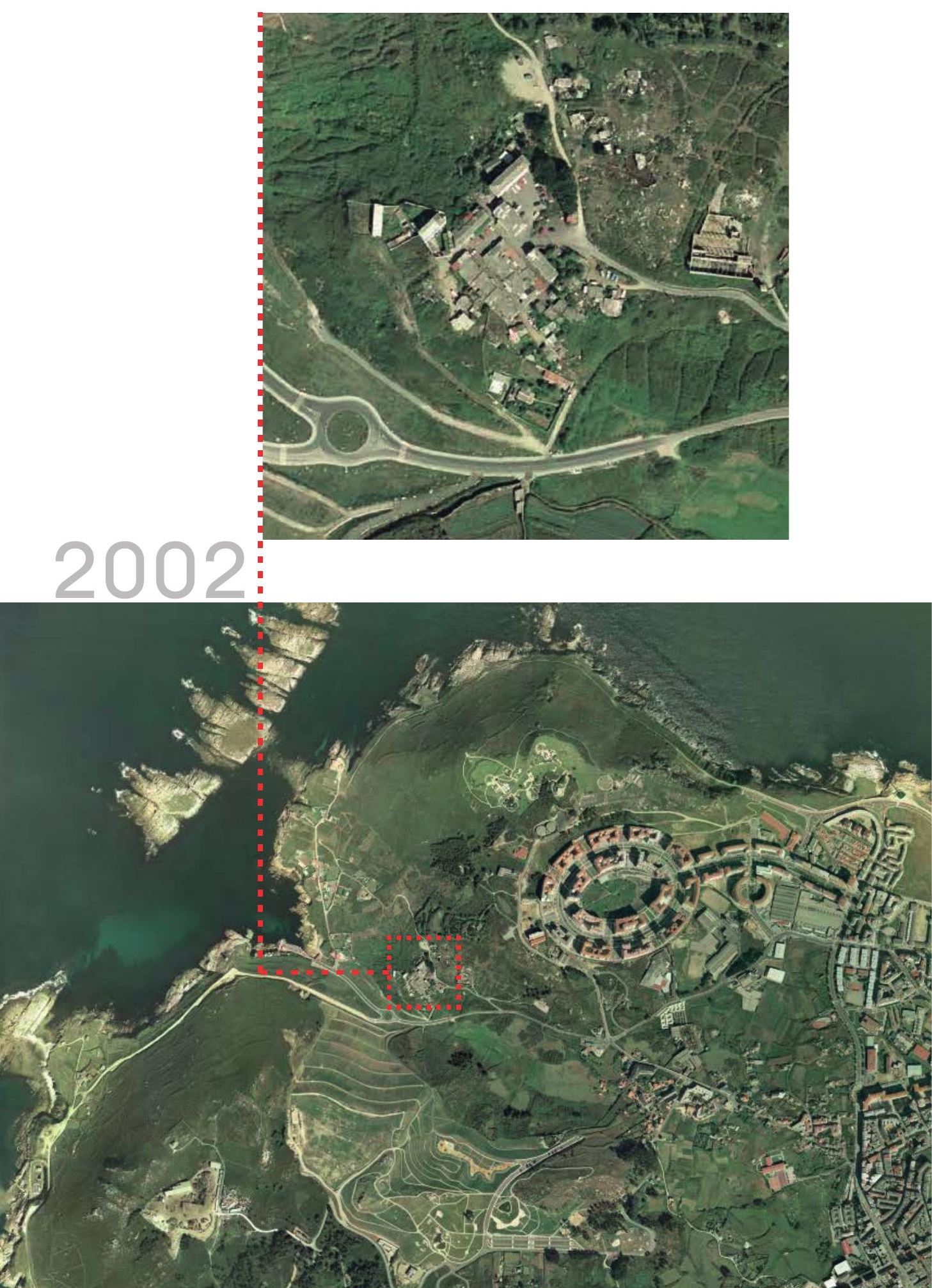

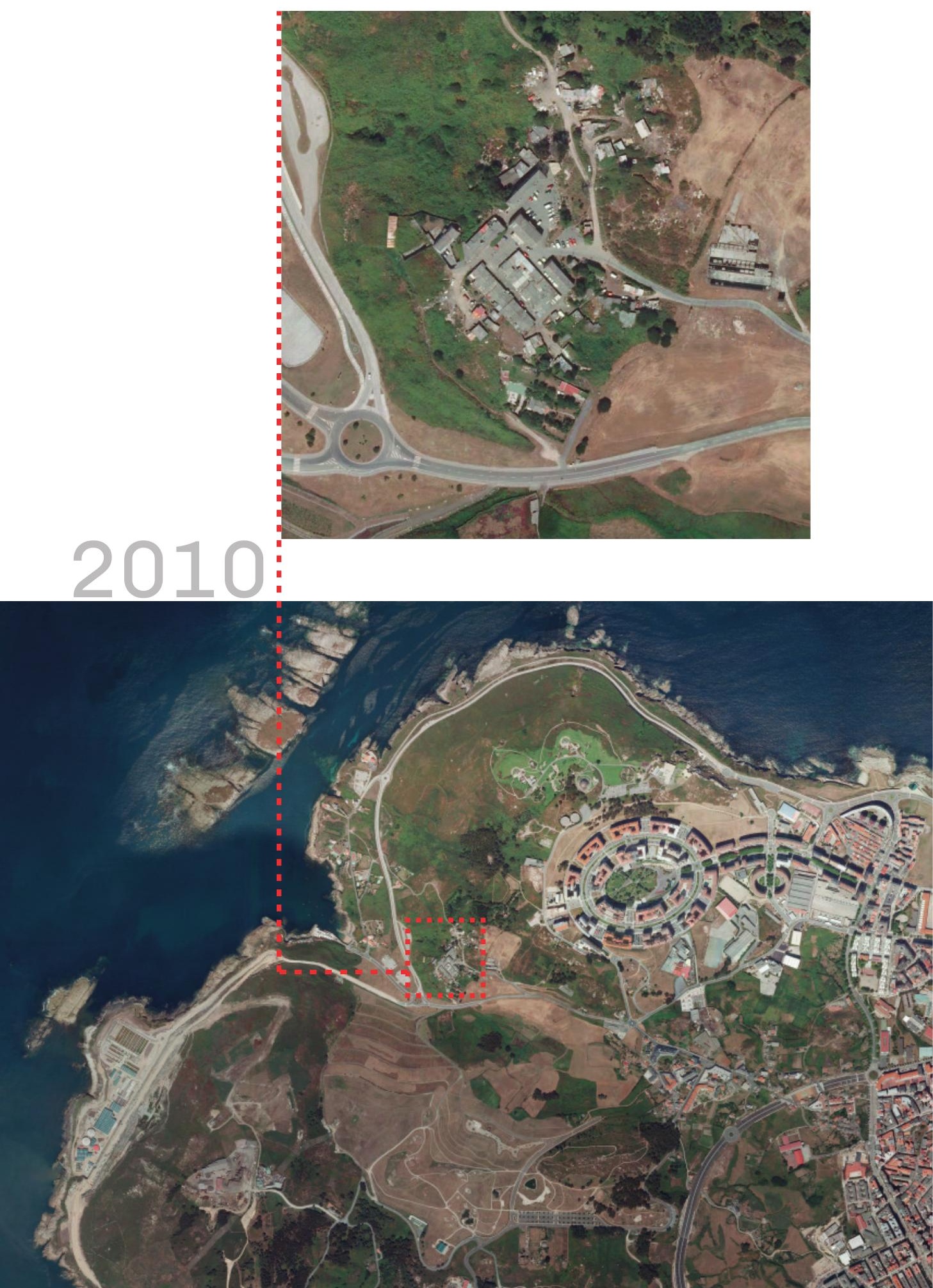
No sabemos lo que quieren hacer aquí, nadie nos informa de nada. El anterior gobierno se fue sin contarnos cómo quedaba todo. Estos son terrenos municipales, somos un barrio más de la ciudad, lo único que pedimos siempre es que arreglen las calles y nos pongan los mismos servicios que a los demás. Ya tenemos casas, que son del Ayuntamiento, ellos son quienes tienen que arreglarlas, o al menos que nos dejen los materiales o nos ayuden a comprarlos y ya las reparamos nosotros. Pero nada, aquí somos invisibles.

-Carlos Gómez, veciño e presidente da AAVV do Campanario 
IAGO CARRO | Arquitecto e urbanista en Ergosfera

\section{Campanario e a cidade. Sempre máis interesantes}

Unha vez máis, parece que comezan os movementos para o desenvolvemento dos plans urbanísticos na zona do Portiño, 0 Campanario e San Pedro de Visma.

En termos sociais e políticos, o único escenario xusto e razoable é que as veciñanzas afectadas teñan a posibilidade de participar no seu deseño e decidir o seu futuro: ben permanecer nos seus barrios, por suposto urbanizados e mellorados tras décadas de abandono municipal e paralización urbanística, así como coas vivendas precarias transformadas ou rehabilitadas; ben quedarse no ámbito, pero nunhas novas vivendas como fórmula de realoxo definitivo; ou ben calquera outra solución compensatoria ou habitacional coa que estean de acordo.

Desde a perspectiva urbanística e do interese xeral para A Coruña, non todas estas posibilidades son igual de desexables: o mellor para a cidade é que a gran maioría dos lugares e edificacións que conforman o ámbito permanezan onde están na actualidade, é dicir, que sexa o planeamento o que configure un proxecto urbano inclusivo. Non só porque non hai ningunha razón técnica para eliminar todo o que acontece nun territorio de medio millón de metros cadrados e xa habitado, senón porque en termos de singularidade urbana e arquitectónica, acolle como mínimo tres pezas cuns valores formais e históricos de grande interese patrimonial e completamente desprotexidas polo PXOM: o barrio do Campanario, as casetas de pescadores do Portiño e o conxunto de vivendas e camiños da Pedra da Barca e Resíos.

Se se pensa no futuro deste territorio, que sería un mundo interesante?

Sería un no que un gran corredor verde a media ladeira conecta os parques do Monte de San Pedro e Bens atravesando un barrio coa intensidade de vida de rúa, a historia, a escala e a com- 
posición formal do Campanario; un no que se pode pasar pola Pedra da Barca e Resíos por ese marabilloso trazado curvilíneo do camiño orixinal ao monte de San Pedro; un no que se pode sentir a vertixe de enfrontarse á paisaxe costeira desde o camiño peonil que dá forma á escala humana radical das casetas de pescadores do Portiño; un no que o val de Visma e algúns dos descampados da zona son mantidos como espazos de reserva funcional e produtiva, polo que poida pasar no futuro coas nosas necesidades e aspiracións ecolóxicas; un no que a gran maioría dos tecidos e construcións que hoxe compoñen o ámbito conforman xunto ás novas pezas un territorio rico e diverso en tipoloxías arquitectónicas, experiencias urbanas e memorias populares; un no que eses novos elementos son introducidos dun xeito progresivo, desbotando os tempos invasivos da práctica urbanística convencional e priorizando a resolución das carencias en termos do dereito á cidade das veciñanzas actuais, por exemplo, rompendo o seu illamento mediante conexións cos Rosales e San Pedro de Visma dun xeito digno e decididamente urbano.

Porque é bo para as persoas que habitan o ámbito na actualidade, se o seu desexo é quedarse e mellorar ás súas condicións de vida. Porque é bo para as veciñanzas dos futuros desenvolvementos, que chegarán a unha zona con actividade urbana desde o primeiro minuto, cunha rede de cotianidade xa tecida e con cousas e lugares con nome. E porque é bo para o interese xeral da cidade, que expandirá o dominio da súa urbanidade nun territorio que, sen dúbida, pode ser aínda máis interesante. 

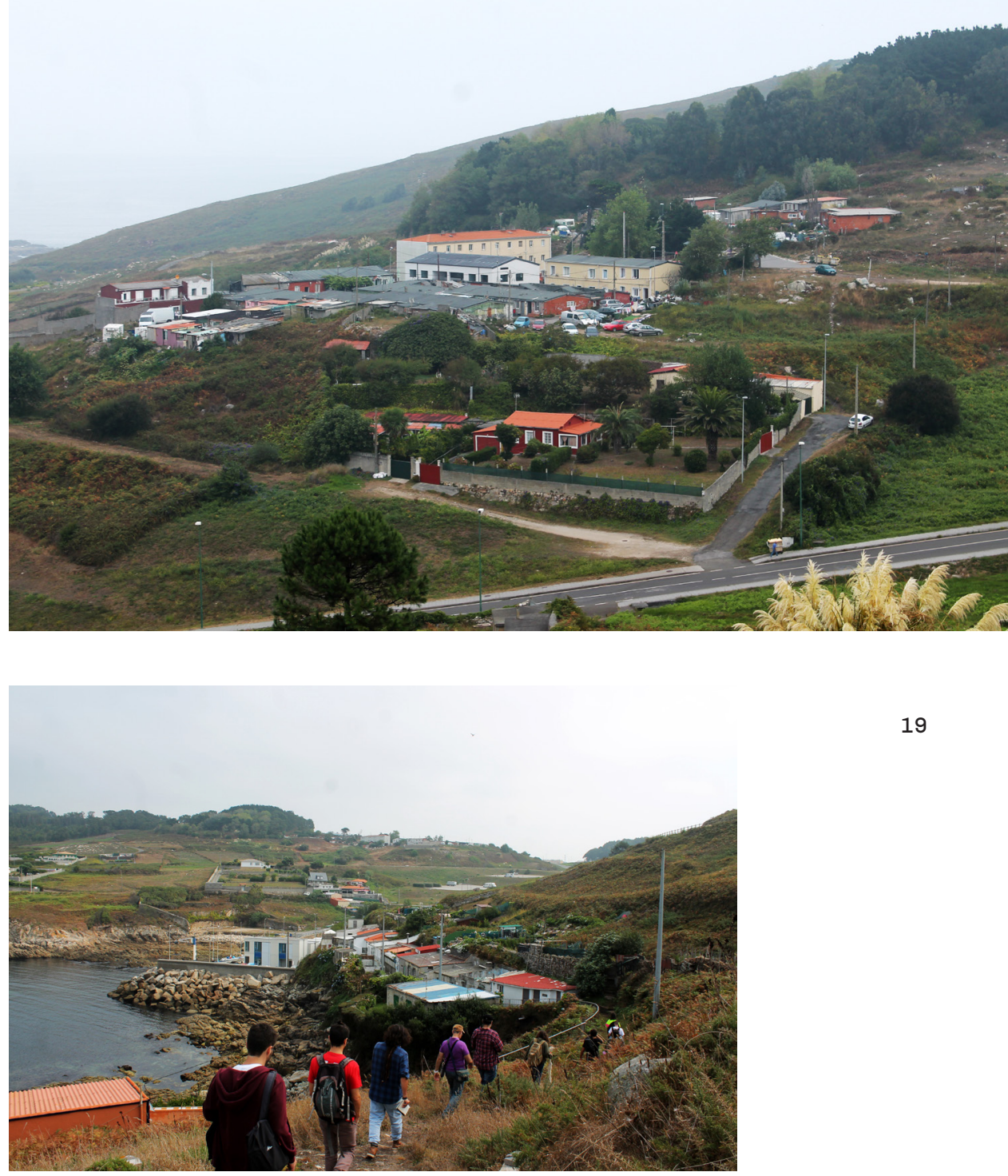


\section{Contexto urbano do Campanario.}

Ergosfera, outubro de 2019.

प o Campanario

Camiños desde $\mathrm{O}$ Campanario ata chegar a unha beirarrúa

$\square$ Visma e Porto de San Pedro (Tecido orixinal/ Pezas a partir dos 90's)

Grupos de vivendas dos 50's

Usos infraestructurais e industriais

Usos infraestructurais e industriais no pasado

$\square$ Actividades e equipamentos privados

.. Actividades e equipamentos privados no pasado

$\square$ Parques

$\square$ Desenvolvementos residenciais dos 90's

$\square$ Equipamentos públicos

- Paseo maritimo

Casetas de pescadores / Grupo de vivendas do Portiño

$\square$ Vivendas unifamiliares no Portiño e na estrada do Portiño

$\square$ Outras vivendas e edificacións

-... Outras parcelas (Pechadas / Singulares e con usos no pasado)

Posibles patrimonios arqueolóxicos

* Ámbitos urbanos con valores patrimoniais (non recoñedidos no pXom)

No Paradas de bus máis próximas

GPS Farmacias, panaderias e supermercados máis próximos

- Ámbitos dos plans parciais ou poligonos contidos no PXOM

Ambitos dos plans parciais ou poligonos contidos no PXOM

Datas:

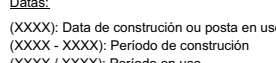

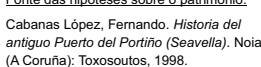

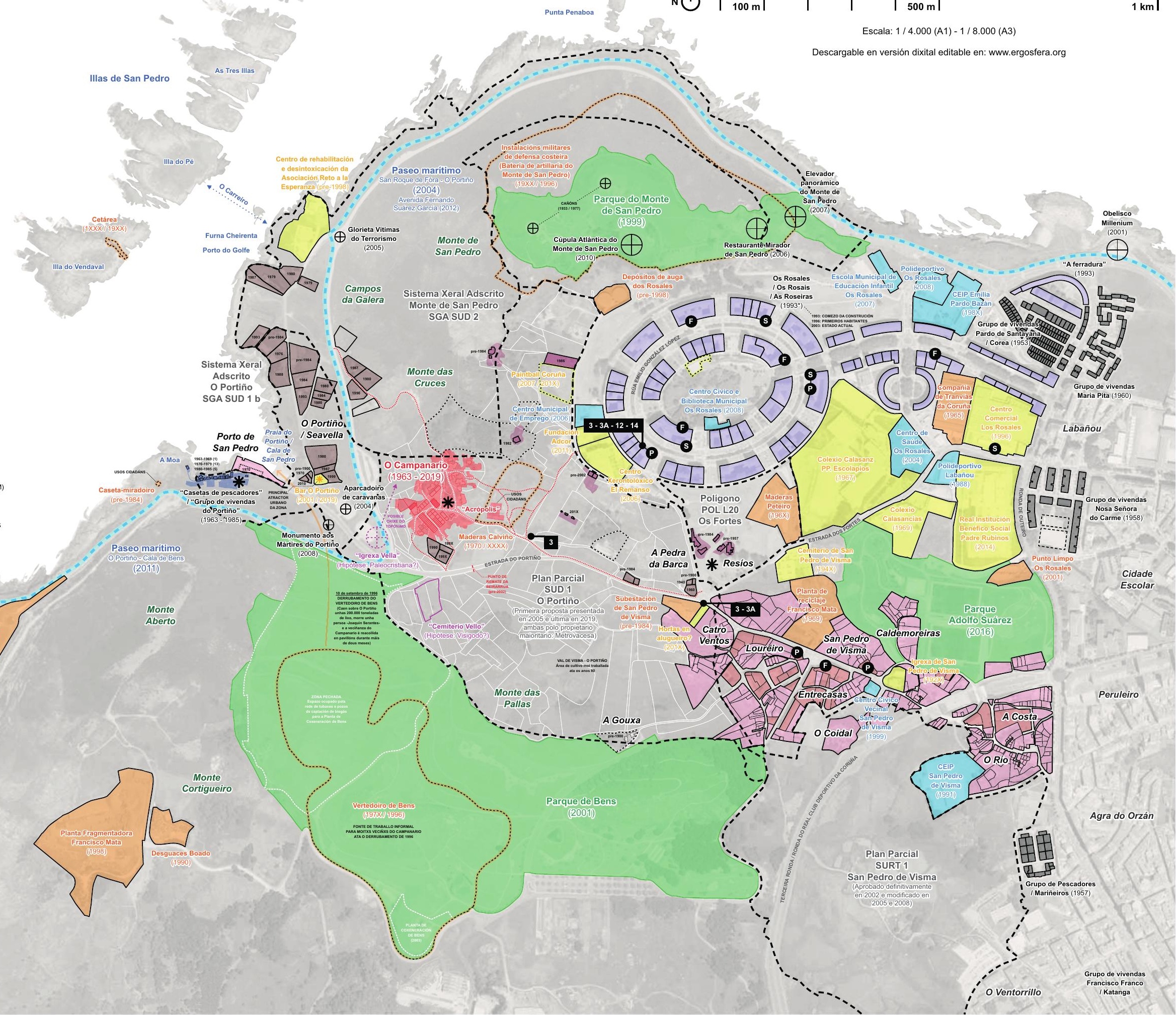


Estamos preocupados porque las familias que dependen de una pensión, si denuncian que su casa está en malas condiciones, que tiene muchas necesidades, entonces te obligarán a marcharte, a dejar tu casa. Ponen en los papeles la obligación de salir para un piso. ¿Para dónde? Yo ya tengo una casa, no tengo por qué irme, este es un barrio del ayuntamiento, tienen la responsabilidad de arreglar las casas, de mejorar el barrio. Pero así es una trampa, si dices que la casa está mal, te obligan a marcharte a un piso que no podrás pagar, si no dices nada o dices que está en buenas condiciones, no te ayudan en nada. Nos sentimos atrapados, en una trampa. $Y$ con las noticias sobre la urbanización que quieren hacer, la gente está asustada, claro que lo está.

-Veciña do barrio do Campanario. 
XIAO VARELA | Concelleiro de Rexeneración Urbana e Dereito á

Vivenda do Concello da Coruña entre os anos 2015 e 2019

\section{Os asentamentos precarios na cidade da Coruña}

A historia dos asentamentos precarios da cidade da Coruña é a historia da invisibilización e marxinalización da pobreza, ao ditado dos procesos urbanísticos.

Para mostra, o que fora un dos maiores asentamentos de Galicia, o barrio de Penamoa, creado polo Concello da Coruña nos anos 70 coa reubicación forzosa dos habitantes da Cubela no proceso de construción da estación de autobuses e a primeira gran superficie comercial da cidade, un asentamento precario, que logo da súa creación, foi abandonado á súa sorte nun proceso de marxinalización radical, ate que a comunidade que o formaba voltou a ser molesta para os intereses urbanísticos por estar no camiño da terceira rolda, cuxa construción a principios de este século, motivou de novo o desmantelamento do asentamento e a expulsión dos seus habitantes.

O que sucedeu en Penamoa, podería repetirse no barrio do Campanario, xunto coas Rañas e a Pasaxe, un dos 3 asentamentos que se manteñen na cidade da Coruña a día de hoxe. Creado no ano 1962 por iniciativa municipal, en terreos cedidos por un mecenas para reubicar a persoas empobrecidas que malvivían no centro da cidade, e levalas á traseira da cidade, un lugar absolutamente periférico naquel momento, onde se situaba todo o que a cidade non quería ver, como o vertedeiro ou o emisario de Bens.

Os primeiros barracóns, de iniciativa municipal, eran pouco máis que galiñeiros, pero foi a forza da comunidade e de algunhas das persoas que se preocuparon polo barrio como o Padre Villa ou Ramón Pérez Basich, presidente da Asociación de Veciños durante moitos anos, os que acadaron que o Campanario fose crecendo cohesinado e sen os problemas de convivencia e marxinalidade que afectaron a outros asentamentos como o de Penamoa.

Actualmente o barrio, a pesar das súas carencias en materia de vivenda, mellorou os seus servizos básicos e dispón dun parque 
infantil dende o ano 2016, do saneamento do que careceu dende a súa creación e viu reformado de maneira integral o seu centro social, que por fin ten condicións homologables aos equipamentos do resto da cidade.

No barrio do Campanario habitan case 300 persoas, das que practicamente unha terceira parte son menores, de novo o seu futuro pende dun dos desmesurados desenvolvementos urbanísticos contidos no Plan Xeral aprobado no 2013, que contemplaba 25.000 novas vivendas nunha cidade estancada poboacionalmente e con case 20.000 vivendas baleiras, en concreto o Solo Urbanizable Delimitado do Portiño (SUD1), un desenvolvemento de 4.000 novas vivendas nun entorno cun gran valor paisaxístico e que pode levarse por diante o barrio e os seus habitantes.

Pero esta vez, os intereses urbanísticos teñen diante unha comunidade cohesionada cuns dereitos consolidados, unha comunidade que habita ese territorio dende hai máis de medio século e vai reivindicar lexitimamente o seu dereito á cidade, a seguir habitando un territorio do que xa forman parte.

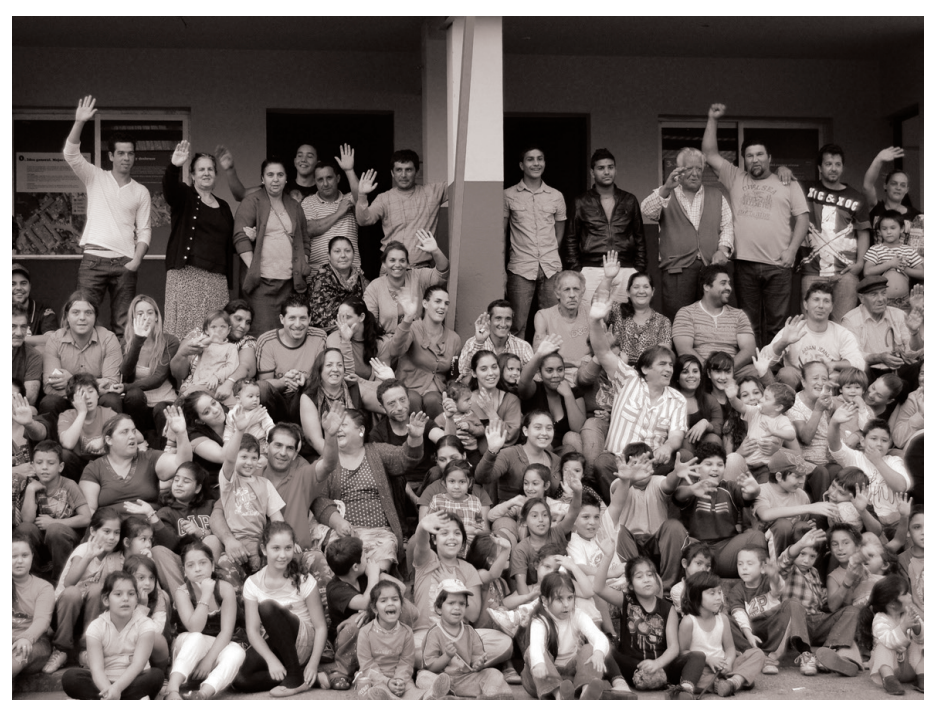


Es la lucha que tuvo el barrio siempre. Lo digo con mucho orgullo: es un barrio peleón. Se equivocaron con nosotros, pensaron que nos íbamos a conformar. El problema del barrio del Portiño es que siempre quisieron manipularlo, hacer en él lo que quisieron. Pero no fue así porque teníamos herramientas muy importantes. Nos criamos todos juntos, y también hubo quien nos enseñó a pelear. Porque hasta a pelear hay que aprender. Cuando fue lo del pabellón, apareció un montón de gente, como decía el alcalde, revolucionarios profesionales. Todas las manifestaciones fueron pacíficas, nunca hemos tenido ningún altercado con nadie. Tenemos la suerte también de que, para las manifestaciones, va el $100 \%$ de la gente. Es lo bueno que tenemos, que cuando hay que pelear no se queda nadie en casa.

Sin duda el ADN de nuestro barrio es la lucha.

-Ramón Pérez, veciño e anterior presidente da AAVV do Campanario. 


\section{O CAMPANARIO. HISTORIA DUN BARRIO}

Enrique Vilariño e Joaquín Moyano asinan co concello a cesión dos terreos onde se levantará o barrio, incluíndo a condición de destinarse á construción de vivendas sociais.

Construción de 44 infravivendas en barrancóns en dúas ringleiras baixas.

O concello aproba a construción da refinería da Coruña entre o val 1964 de Bens e Nostián.

Chega ao barrio o Padre Villa. 0 primeiro que fai é habilitar 3 novos barracóns: un para estudar, outro para cociña e un comedor para a rapazada.

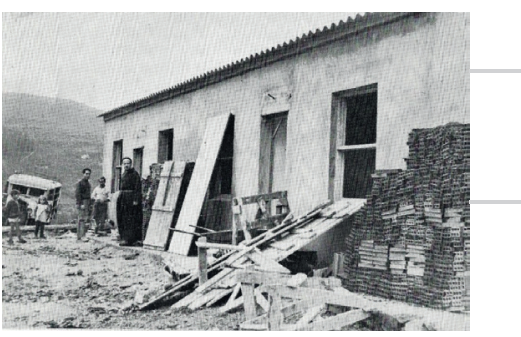

Cáritas comeza a construír un bloque de 12 vivendas en 3 alturas. 0 concello instala o vertedoiro municipal na ladeira de Bens.

Finaliza a construción do bloque de 12 vivendas e chegan máis familias desaloxadas das áreas de San Diego e Casablanca.

O concello conecta o servizo de auga potable no barrio, 13 anos despois da súa construción.

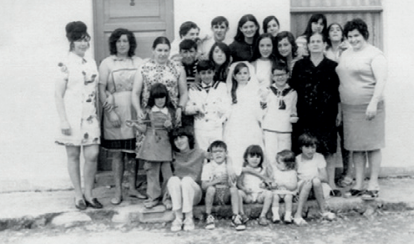

Chegada ao barrio de Dña. $\mathrm{M}^{\mathrm{a}}$ Teresa Salorio quen apoiou aos enfermos da tuberculose que naquel momento asolaba á poboación.

1965 O Padre Villa promove a construción de 5 novas vivendas en planta baixa fronte das dúas agrupacións de barracóns, así como un edificio de dúas alturas con 6 vivendas máis.

1967 Constrúese o edificio destinado á escola e ao Teleclube.

O barrio funda a peña de fútbol Agarimo, naqueles tempos o único equipo de fútbol do Estado formado por payos e xitanos.

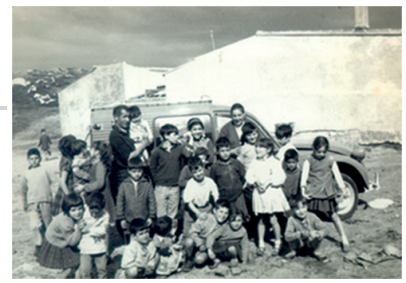

Coa fundación da Cidade dos Muchachos, o Padre Villa marcha para Arteixo xunto con 25 nenos e nenas do barrio.

Cáritas deixa as súas funcións no barrio á asociación Chavós, nun intercambio non acordado coa veciñanza.

Cáritas presenta un proxecto de vivendas no Portiño que finalmen- 1987 te cae no esquecemento.

Peche do Teleclube, que non se recuperará con ningunha das intervencións futuras no barrio.

Comezan a construírse vivendas nas inmediacións do barrio. Catro familias viven xa en chabolas autoconstruídas.

A veciñanza maniféstase na cidade reivindicando unha vivenda digna. 


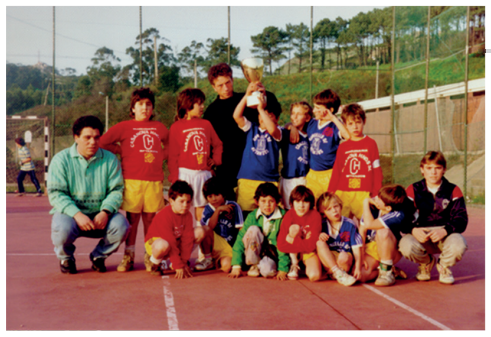

No mes de setembro colapsa o vertedoiro de Bens e derrúbanse $200.000 \mathrm{~m}^{3}$ de basura sobre o val e as vivendas provocando a morte dunha persoa. A avalancha ocupou $500 \mathrm{~m}^{2}$ chegando ata o espigón do Portiño.

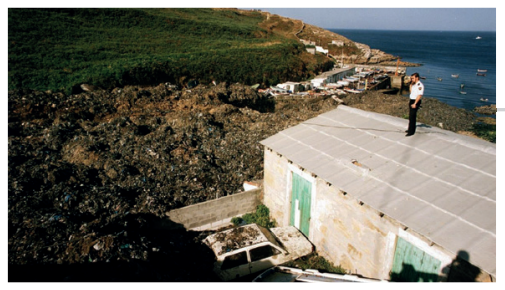

O concello traslada á veciñanza do Campanario afectada polo derrubamento ao pavillón polideportivo Riazor.

A finais deste ano conclúe o selado do vertedoiro.

Inaugúrase o parque Atlántico nos terreos ocupados polo vertedoiro.

Tras varias movilizacións do barrio o concello asfalta as rúas e renova a rede de auga municipal.

A petición veciñal levántase un busto homenaxe ao Padre Villa.

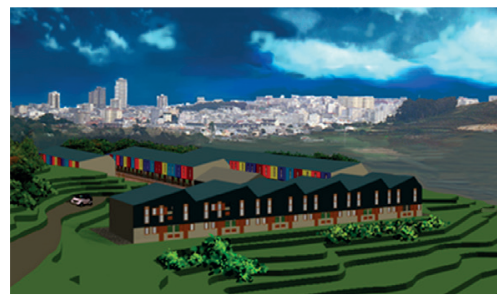

- 1989 A veciñanza recupera a promoción do deporte infantil e xuvenil no barrio colaborando coa Asoc. Xuvenil Brétema.

1996 A veciñanza organízase en patrullas de vixilancia para protexerse do tráfico de drogas e da degradación do barrio.

A veciñanza maniféstase ante o abandono do concello e a negación dun realoxamento tras a catástrofe ambiental.

1997 o barrio constitúe a Asociación de Veciños do Campanario e comunica á asociación Chavós que non precisa a súa presenza.

1998 A veciñanza maniféstase na entrada da escombreira para reivindicar unha solución a 40 traballadores tras o selado.

AAVV Campanario une a súa acción á Asoc. Comunitaria Distrito V e á AAVV San Pedro de Visma.

2000 As negociacións e presións do barrio logran a contratación de 10 traballadores na EDAR Bens.

2001 Un grupo de 20 xoves forma un grupo de Danza Flamenca coa Asoc. Comunitaria Distrito V. Homenaxe ao Padre Villa pola súa labor no barrio.

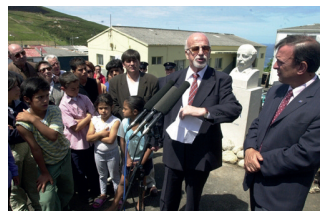

2002 A AAVV e o colectivo InfraDomus presentan un proxecto de rehabilitación do barrio no concello. 
O concello plantea a urbanización da área do Portiño segundo o Plan Parcial que permite construír ata 3.513 viviendas, o $30 \%$ seguindo o modelo de cidade xardín.

Metrovacesa presenta o proxecto de urbanización do sector do Portiño. A Xunta de Goberno Local aproba construír perto de mil chalés adosados e outras 2.200 vivendas repartidas en bloques de ata cinco plantas.

O COAG promove a iniciativa "A cidade dos barrios" cun colectivo de profesionais técnicos que avalía a situación habitacional do barrio.

O concello promove un obradoiro de autoconstrución levado a cabo polo estudo técnico Desescribir a través do cal se realizan importantes melloras na habitabilidade das vivendas e nos espazos do propio barrio.

Fundación Secretariado Xitano, en convenio co concello, realiza a rehabilitación do bloque de vivendas promovido polo Padre Villa no ano 65.

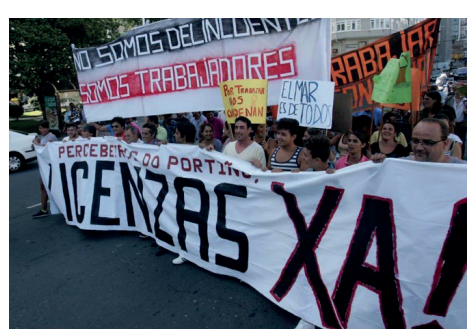

Máis de 55 anos despois da construción do barrio o concello realiza o alcantarillado e a rede de saneamento.

O concello promove a rehabilitación do local veciñal do barrio.
2002 AAVV é chamada a formar parte da mesa de erradicación do chabolismo na Rede Coruña Solidaria.

O clube de fútbol Portiño álzase co título de campión do Distrito $V$ nas categorías Alevín, Infantil e Xuvenil.

\section{5}

2008 o barrio convoca unha marcha pacífica por San Pedro de Visma para denunciar as continuas mostras de racismo.

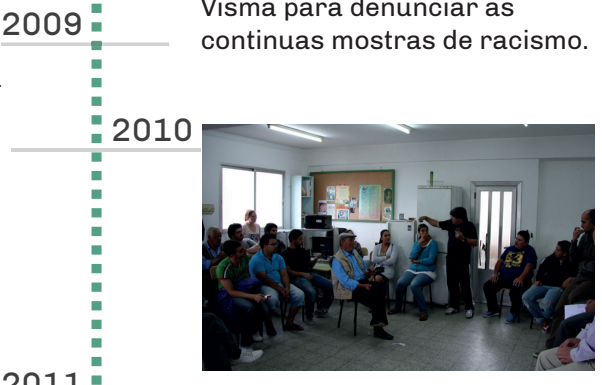

Un incendio na contorna produce importantes danos nas vivendas e obriga ao desaloxo temporal de 300 persoas.
O barrio denuncia o mal estado dos servizos e espazos públicos.

\section{7} Por primeira vez o traballo do servizo municipal de limpeza chega ata O Campanario.

o Campanario esixe a reapertura do local veciñal ante a demora desde o fin das obras. 
CRISTINA BOTANA | Arquitecta e investigadora na ETSAC

O urbanismo ao outro lado do espello

A aprendizaxe sobre os barrios marxinalizados da cidade implica necesariamente mudar a ollada, abandonar esta tendencia a aproximarse a estes lugares como espazos de pobreza que a sociedade ten a responsabilidade de salvar de si mesmos. Son vistos como espazos circunstanciais a determinados foco de pobreza ou colectivos marxinalizados, e non admitimos que estes contextos afondan as súas raíces na nosa forma de facer cidade e de utilizar o urbanismo como un instrumento de exclusión e categorización social. É por iso que o primeiro que debemos facer é virar a mirada cara aqueles axentes, institucionais, académicos, profesionais ou sociais que toman parte nos procesos de segregación urbana. Non falemos máis dos outros, falemos de nós. Teñamos a valentía de despoxarnos de todo o aprendido para por en cuestión o conxunto de prácticas territoriais que teñen conducido á paisaxe urbana e social actual. A segregación urbana é un dos produtos da desigualdade social. As sociedades desiguais construíron cidades sectorizadas e organizadas en niveis de pobreza. A expresión construída desta segregación espacial ofrece varios retratos, temos os barrios de absorción levantados desde os anos 60 nas marxes das cidades, pero tamén están outras solucións alternativas. Son os conxuntos residenciais máis precarios normalmente ubicados en terreos residuais, abandonados ou nos intersticios das fronteiras internas das cidades; compostos por barracóns, infravivendas, caravanas, chabolas ou casetas de obra utilizados como vivenda sen que reúnan as características mínimas de seguridade, salubridade e habitabilidade para ser consideradas como tales. Tenden a estar marcadas por un carácter de temporalidade feita permanencia. Unha permanencia sen dereitos. Pero, por encima de todas estas consideracións, tenden a ser promovidas polas propias administracións públicas que co tempo decretarán a súa "erradicación".

$\mathrm{Na}$ formación académica como arquitectas ou urbanistas rara vez se fala destes lugares, menos aínda como barrios, xa que se 
trata de habitares críticos cuxa existencia pon en cuestión toda a praxe e a dogmática sobre a cidade. Son lugares apropiados fronte ao trauma da expulsión urbana, illas heteroxéneas delimitadas polo que María Prieto Peinado define como membranas asimétricas, que permiten facilmente entrar pero das que é moito máis difícil saír. A través de ditas membranas a cidade interior é invisíbel á exterior até que novamente se produce o choque e os habitares precarios quedan ao descuberto. Entón pasan a ser causa e consecuencia dos males urbanos, patoloxías a erradicar que, no mellor dos casos terminarán por ser desprazadas de novo e recubertas por unha nova membrana protectora. Este é o fenómeno que ameaza ao barrio do Campanario, ao igual que a outras áreas da cidade. Por sorte a veciñanza conta con ampla experiencia na loita veciñal pero o resto da cidadanía e das profesionais temos tamén a oportunidade de por estas desaprendizaxes ao servizo das persoas e acompañalas en todas as loitas urbanas. Temos a responsabilidade de situar a mirada crítica nos axentes de intervención, de comprender que o primeiro paso para a reconciliación de disciplinas como a arquitectura e o urbanismo coas persoas pasa por recoñecer as súas servidumes e as súas faltas, para a continuación poder activar procesos de reparación desde ese recoñecemento. Asumindo que esta reparación só virá ditada polas voces de todos os colectivos agraviados, de todas aquelas e aqueles para quen non foron construídas as cidades nas que habitamos. Por fin escoitar e deixar facer. Pero para poder aspirar a todo isto, hai que atreverse a sentir a vertixe de ver caer esas membranas invisibles que nos rodean a todas de unha ou outra maneira. 
ALBERTO MATARÁN | Docente de Urbanismo na ETSA de Granada

Nuestros barrios como referencia metropolitana frente a la crisis climática y el colapso

\begin{abstract}
Alberto Magnaghi nos enseña que la ciudad metropolitana contemporánea está constituida por una superposición de periferias que predominan sobre los fragmentos que resisten de las áreas históricas. La insostenibilidad es consustancial a unas metrópolis que consumen recursos y generan impactos ambientales inasumibles en este momento de emergencia climática. El cénit del petróleo alcanzado en 2005 indica que estamos en pleno descenso en la disponibilidad de este recurso esencial para el funcionamiento de los espacios urbanos donde habita la mayoría de la población mundial. A la escasez energética (y también de materiales), se le suman los efectos cada vez más evidentes de los impactos ambientales generados por décadas de desarrollismo. Todo ello indica que estamos en una nueva época, el antropoceno, que nos coloca ante un escenario de colapso para el que debemos prepararnos a través de una transición socioecológica que tenga en las ciudades uno de sus principales puntos de referencia.
\end{abstract}

Y son las personas que habitan en las periferias más degradadas las que más vulnerabilidad presentan a estos procesos de escasez y degradación, por lo que deben ser las protagonistas del cambio. Para reconstruir ciudades en transición, es necesario mejorar las condiciones de habitabilidad y de aislamiento de las viviendas construidas desde la revolución industrial al tiempo que se generan procesos de economía circular que disminuyan las necesidades de transporte. Por otro lado, el hábitat urbano debe ser transformado favoreciendo la soberanía energética y alimentaria mediante la producción local de la mayor cantidad posible de los insumos esenciales para la vida. Esto sólo será posible si las ciudades metropolitanas dejan de crecer, se descentralizan y se reorganizan entorno a los barrios y otras centralidades preexistentes. De este modo, las comunidades locales podrán rearticularse y afrontar de manera colectiva el colapso como ya ha ocurrido en otros momentos traumáticos de nuestra historia reciente. 


\section{JOSÉ LUIS MARTÍNEZ}

Arquitecto participante no obradoiro

La relación que existe entre el capitalismo y la forma en la que el ser humano habita el territorio es directa. Mi experiencia personal, en condiciones de precariedad laboral, me han llevado a vivir en infraviviendas por un período prolongado de tiempo.

En mi caso concreto, éramos todos estudiantes, y al menor problema nos juntábamos todos a discutirlo y luego trasladábamos nuestras exigencias al casero. Actualmente la mayoría de la gente que vive en infraviviendas no son estudiantes sino trabajadores precarizados y/o personas que huyen del precio de la vivienda. En esta situación actual, la itinerancia y la heterogeneidad de la gente con la que convivo es muy alta, ello implica una falta de cohesión, de formación de grupo; por tanto, ahora el casero hace lo que quiere cuando quiere, y la gente que puede al menor problema marcha.

En el barrio del Campanario, sí hay bastante cohesión, y existe una asociación vecinal que les permite ejercer cierta presión, y así obtener cierta protección frente a los ataques externos.

A pesar de tener un origen distinto, la precariedad es el denominador común, y ésta existe porque hay alguien que se aprovecha de dicha situación, y por tanto la crea; es decir, la riqueza de unos pocos se basa en la pobreza de muchos.

Esa cohesión dentro del grupo precarizado es la que fortalece el gueto, hecho diferencial con respecto a las infraviviendas en las que vivo, es una cuestión que se retroalimenta, el hecho diferencial, ya sea raza, sexo, poder adquisitivo, etc., es usado por el capital para arrinconar al objeto a precarizar. En el caso del barrio del Campanario, se trata de un colectivo de etnia gitana y payos de escaso poder adquisitivo. Al constituirse en gueto, ahora se consolida como hecho diferencial visible, incluso de forma material en el territorio; son un barrio, al que se le denomina de forma mezquina poblado, evidenciando su origen distinto al hecho urbano y por 
tanto, al ser ajeno a éste, prescindible, movible. Ese grupo humano ya adaptado a ese entorno, son mariscadores, puede ser expulsado si el capital así lo quiere.

El derecho al hábitat no debe ser sólo un derecho de acceso a lo que ya hay, sino el derecho a cambiarlo.

A la pregunta de si es la segregación espacial una causa de la pobreza o sólo su consecuencia, el geógrafo y sociólogo urbano David Harvey responde:

"...los barrios segregados suelen tener problemas de acceso a los colegios, los servicios de salud son pésimos, el sistema de recolección de basura no funciona bien y la gente vive en un entorno urbano desastroso; hay mucha cesantía y una de las pocas maneras de ganar dinero es entrando al negocio de la droga. Entonces lo que ocurre ahí es que el modelo de pobreza se replica por la segregación de esta comunidad en una zona de la ciudad donde las oportunidades para surgir son muy restringidas, porque no hay servicios adecuados". 
LUCIANO ALFAYA e PATRICIA MUÑIZ | Invest. e arquitectos en MMASA

\section{As Cidades Invisibles}

A paixón polo descoñecido sempre nos acompañou. Pode que non do mesmo xeito, pero todo ser humano ten ansias de coñecer o que lle está oculto, o que non se pode ver. Italo Calvino revelaba, entre outras, as cidades escondidas nas que a pesar das desgrazas sempre se pode atopar o optimismo. Win Wenders percorría Lisboa na procura de imaxes que lle transmitisen un sentimento que non era posible atrapar. Van der Keuken contaba que os fotogramas mais intensos eran os que non existían.

As cidades agochan mais do que contan. As cidades, e quen as dirixe, semellan amosar tan so unha das súas facianas dentro da estrutura poliédrica que é o tecido urbano. Nun contexto de rápida lectura, de Twitter e Instagram, a mirada que se ofrece é a que configura o imaxinario de quen visita a cidade. Incluso de quen reside nela.

Co paso do tempo, semella que crecen as raíces, e o sentimento de non existencia contáxiase. Así, ao logo dos anos, foron desaparecendo barrios, casas e incluso persoas, sobre todo mulleres, que agochadas fronte calquera tipo de barreira, acababan por ser invisibles. Pero, como dicían en México no día de mortos, mentres alguén siga a pensar en ti, nunca desapareces de todo. 
Dende hai tempo o urbanismo hexemónico en Europa leva apostando pola especulación do chan e a inflación inmobiliaria cando se trata de planificar a organización social e espacial do ecosistema urbano, convertendo as persoas que traballan no urbanismo en simples axentes de mercado e expulsando da cidade aquilo que sobra para a súa visión neoliberal. Pola contra, cada vez máis persoas entendemos a cidade como un ente complexo, formado de relacións, desexos e contradicións, non só de infraestruturas. Neste senso, sinala David Harvey, un dos principais investigadores urbanísticos da actualidade dende unha perspectiva emancipadora, que "a cuestión de que tipo de cidade queremos non pode divorciarse da cuestión de que tipo de persoas queremos ser, que tipo de relacións sociais buscamos, que relacións coa natureza mantemos, que estilo de vida desexamos ou que valores estéticos temos" no seu libro Cidades rebeldes (Akal, 2013).

Deste xeito o racismo e a xenofobia reprodúcense nas cidades, como sinala a socióloga Keina Espiñeira "a fronteira chega ao centro das cidades e impacta nas sociedades xerando novas xerarquías, novas diferencias e discriminacións. A fronteira espállase dentro das sociedades que habitamos a través da clandestinización dos suxeitos, no control da mobilidade e no non recoñecemento de dereitos. É dicir, as fronteiras reprodúcense en termos de desigualdade social". Polo tanto existen fronteiras visibles, físicas, territoriais, incluso militarizadas pero tamén existen fronteiras sociais, que son invisibles e que se reproducen a un nivel complicado de codificar, no ámbito da cidadanía, dos dereitos e das relacións sociais. Isto último é o que pretenderon os obradoiros de Arquitecturas Ambulatorias, xerar un espazo de traballo sobre o dereito ao territorio e o acceso pleno á cidade sen ningún tipo de discriminación e onde poder ir desmontando esas fronteiras sociais invisibles e conseguir pensar e concretar unha cidade para todas as persoas. 


\section{CRISTINA CAMPILLO}

Alumna da Escola de Arquitectura participante no obradoiro

La arquitectura debe hablar de su tiempo y lugar. La arquitectura debe de dar respuestas a las necesidades de unos individuos. Debe de estar pensada con y para ellos. La arquitectura sólo se considera completa con la intervención del ser humano que la experimenta y debe pertenecer al entorno donde va a situarse, potenciando el paisaje en vez de desgraciarlo. Pero, ¿cómo aspirar a dicho estado? La arquitectura ha de enseñarse y acompañarse. Ha de ser participativa, multidisciplinar y curiosa. La arquitectura ha de ser digna, confortable, práctica, firme y bella. La arquitectura hemos de ser todos.

Para que un barrio marginalizado, como el caso de estudio, llegue a ser arquitectura se han de llevar a cabo procesos de participación e implicación directos en los cuales se estudien y den respuestas a las necesidades de estos individuos, a la vez que se les enseña a hacer arquitectura.

El urbanismo ha de abordarse desde una trama compleja, como una amalgama de formas y usos, entendiendo que no se trata de un sistema preconcebido e impuesto, sino, de un caso compuesto por distintos tipos de redes que generan posibilidades muy variadas.

No obstante, lo más importante a la hora de abordar el proyecto es no perder de vista lo que tenemos y lo que queremos tener para reflexionar sobre los medios y el camino a seguir. La arquitectura marginal no es más que un caos y abandono del proyecto arquitectónico desde la concepción de unas preexistencias hasta la resolución de un resultado, y es en esa búsqueda de una organización y pautas de proyecto donde nos deberíamos sumergir a la hora de abordar algo tan complejo como el barrio de O Campanario. 
ROcío BOTANA | Traballadora social, invest. na Fac. de Socioloxía

Recoñecemento e reparación, alén da integración social

A intervención social desenvolvida no Norte Global reflicte a pervivencia de formas de colonialidade en canto que as súas prácticas están manifestamente dirixidas a lograr a "integración" ou conversión dos suxeitos ao sistema hexemónico da modernidade.

Segundo as perspectivas decoloniais exploradas durante estas xornadas, o Traballo social exerce na actualidade o seu privilexio sobre os colectivos cos que actúa, sendo o brazo executor das medidas políticas e institucionais que someten ás comunidades vulnerábeis. Dende o rostro amábel da solidariedade oenegerista e a integración, ocultan unha conversión forzosa de pensamento e formas de vida e a usurpación das voces emancipadoras. 0 desenvolvemento mesmo da profesión ten as súas raíces na tradición da caridade e da filantropía; esta herdanza explicaría a permanencia das condutas paternalistas, vitimizadoras e moralizadoras.

"O Traballo Social é unha profesión e disciplina moderna con herdanzas coloniais e visión eurocéntrica que herda o afán de incluír ao outro na civilización moderna occidental" e "asume a clasificación dos seres humanos, a cousificación e a negación das súas propias existencialidades". Gómez-Hernández, 2015.

Neste senso, cabería facer unha reflexión máis profunda do concepto de integración, senón rexeitalo por completo, mais alá da convivencia entre paios e xitanos en cuestións sociais ou urbanística; a interculturalidade non é unha categoría teórica, é un imperativo ético. 0 concepto mesmo de integración parte dunha posicionalidade clara da sociedade maioritaria sobre aqueles suxeitos a integrar, entendido dende unha tripla lóxica:

1. Lóxica de homoxeneidade: as comunidades excluídas deben adaptarse e absorber a cultura e normas da sociedade maioritaria (renunciando ás propias) para lograr a súa integración. Desa forma, o Traballo Social ignoraría unha xerarquía que po- 
siciona aos colectivos subalternos nun punto da pirámide da cal non se moverán mentres perduren ditas estruturas e institucións de privilexio.

2. Lóxica de vontade: a comunidade xitana négase a aceptar as normas e costumes normativas e por tanto a integración pasará por renunciar á súa cultura para adaptarse e así evitar rexeitamento. Exime á sociedade maioritaria de favorecer esa suposta integración ou convivir na diversidade.

3. Lóxica de status: fundaméntase na ficción de lograr igualdade mediante ascenso social; na medida en que melloren as condición económicas, habitacionais, laborais, etc., lograrase a integración plena e o seu benestar.

Sobre esta cuestión, a recente indignación ante os prexuízos deixaron paso ao daltonismo social ou á cegueira das cores para referirse a "retórica da neutralidade en termos raciais". Considerar o racismo como unha lacra xa superada e unha inxenuidade conveniente para a aqueles que manteñen o privilexio e a hexemonía.

Con estas xornadas pretendíase facer unha crítica profunda a estas lóxicas impostas desde o urbanismo e o traballo social, como sistemas imbricados nos plans de acceso á vivenda ou erradicación de chabolismo. Sen recoñecer o despoxo e a violencia exercida no pasado, neste caso contra "o problema xitano", trabállase dende a superioridade paternalista para transformar os barrios segregados a condición de que acepten sen contemplación os imperativos do sistema-mundo (Wallerstein, 2005) e non se resistan á súa forza pedagóxica.

Tratar de buscar solucións baixo as mesmas premisas e no marco das mesmas institucións que provocaron, manteñen e empeoran a situación é un sensentido. Recoñecemento e reparación son as dúas claves fundamentais para comezar a pensar nun mundo novo. 
Las oenegés, asociaciones que reciben subvenciones de la Xunta, de la Unión Europea, están montando un chiringuito a cuenta del barrio. Un chiringuito donde el barrio parecía que no tiene voz propia, ellos hacían y ellos deshacían. Y aunque hicieran cosas buenas... lo que no puedes hacer es tapar la voz del interesado, llegó un momento en que ya decidían por nosotros. Y al final les montamos la guerra.

Es que a ver, a cualquier oenegé le interesa que sigan los pobres. Tienen varios empleados, tienen directores... les interesa mantener su trabajo. Eso se ve de forma muy clara. Están equivocados. Venden una imagen de barrio y de los gitanos que perpetúa la idea de atraso, de pobreza. Pero es un barrio de trabajadores: hay albañiles, va a las ferias o al percebe, hay jardineros, hasta tenemos un policía local. Pero no, ellos venden esa imagen decaída y victimista. Están conformes con esa realidad, viven de ella.

En mi barrio se ha demostrado, son luchadores. Seguimos estando machacados, pero no se queda nadie de brazos cruzados, pelean.

-Ramón Pérez, veciño e anterior presidente da AAVV do Campanario. 
SEBIJAN FEZJULA | Invest. CES Coimbra, membro de Kale Amengue

Racism and Whiteness in an Anti-Roma Europe

In my presentation", I am using the metaphor of "the permanent State of exception" to discuss contemporary state politics that dehumanize the Roma. This metaphor allows me to centre the analysis on "the layered interconnectedness of political violence, racialization and the human" (Weheliye, 2014, p. 1) within the domain of modern politics, and, in particular, to describe the construction of Roma as almost humans or non-humans. The social and political construction of the Roma bodies as "naturally prone to criminality" hence, as a specific threat to the white order, have placed the Roma body as a body that needs to be constantly "integrated", "corrected", observed/controlled. In this regard, Antigypsyism is organised in the realm of "exception" and the Roma are constructed as a threat to the state.

Having said this, I have argued that the analysis of Antigypsyism requires a focus on the racialization of Roma as a set of political relations and connections that aim to "discipline humanity into full humans, not quite-humans and nonhumans" (Weheliye, 2014, p. 3). Therefore, it is within the "permanent State of Exception"that the justifiable and legitimized violence over the Roma body takes place, driven by its construction as racial Otherness/ threat. This notion illustrates the creation of exceptional procedures of restriction, necessary control and discipline exercised in a regime of police States. Antigypsyism is the enabling element that allows all the circumstances and political torsions aforementioned. Thus, the projects of "integration", "assimilation" flourish

\footnotetext{
1. My presentation titled Racism and Whiteness in an Anti-Roma Europe, departure from my recent article The Anti-Roma Europe: Modern ways of disciplining the Roma body in urban spaces published in the Brazilian journal Direito e Práxis. The article is product of the work developed in the project POLITICS - The politics of anti-racism in Europe and Latin America: knowledge production, decision-making and collective struggles in the Centre for Social Studies, University of Coimbra.
} 
under such ideology follows an ideological purpose, what Maeso calls a "civilizing mission" - a way of "correcting a pathologised "way of being [Roma]" (Maeso, 2015, p. 60). Structural violence is thus legitimized when it is in the name of "saving the Roma from themselves". I consider all those policies for "Roma Integration" as policies that have reproduced Antigypsyism while aiming to "correct Roma way of being", or as defined by Maeso (2015) "public policies and "active inclusion"and "empowerment"initiatives are therefore implemented as a civilising and disciplinary programme" (2015, p. 33).

Consequently, Antigypsyism is naturalized and it has not been part of such theorizations because Roma are (un)seen as being in Europe but not from Europe, Accordingly, I argue that the processes of racialisation and dehumanisation of the Roma have become necessary to the maintenance of whiteness and white supremacy (Fejzula, 2019, p.2). 
CAYETANO FERNÁNDEZ | Invest. CES Coimbra, membro de Kale Amengue

Antigitanismo de estado y autonomía política romaní: claves para la comprensión y la acción

El sistema de dominación racial que llamamos antigitanismo a la vez que condiciona cada faceta de nuestra vida social como gitanos en un mundo payo, genera también sus propios subsistemas de legitimación. Estos sistemas a veces son evidentes y fáciles de detectar, como ocurre en el caso de los medios de comunicación o de prácticas abiertamente represivas como la vigilancia y violencia policial basada en el perfil racial; en otros casos el compromiso con el racismo antigitano no resulta tan evidente, pero acaba siendo igual de pernicioso, en este segundo sentido podríamos agrupar políticas educativas, la labor "civilizatoria" de los trabajadores sociales, políticas urbanísticas o las mismas narrativas de liberación del mundo blanco que apuntalan la división racial de las sociedades en que vivimos y sirven de obstáculo para el desarrollo de la voluntad y la agenda política de los pueblos racializados.

En definitiva, el antigitanismo es la ideología que se esconde tras el Estado y sus estructuras de poder y como tal debe ser entendido y confrontado. Es en esa matriz donde las políticas de racialización del espacio urbano se encuadran. El surgimiento de guetos para contener y recluir en la periferia a la población gitana se da en casi todas las grandes urbes del Estado español, siguiendo los mismos patrones y en un mismo periodo temporal, lo que demuestra una intencionalidad política. A la vez, en un país donde las luchas vecinales han tenido una importante presencia de los años de la Transición hasta la actualidad, en algunos momentos desempeñando un papel clave en la transformación social, las referencias al carácter racializado de los espacios donde esas luchas se desarrollan brillan por su ausencia. Comúnmente nos encontramos con que muchas de esas plataformas vecinales son lideradas por la minoría paya de esos barrios, los cuales enfatizan el carácter de clase de esa lucha contra el empobrecimiento a 
la vez que simultáneamente aíslan el carácter racial del conflicto, provocando así la desafección de nuestra gente que mira con desconfianza y recelo sus narrativas y modelos de lucha y, finalmente, acaban siendo acusados por líderes payos de padecer de una supuesta pasividad e inmovilismo por no comulgar con la agenda política blanca y sus formas.

Es necesario comprender que para que exista "Blancopolis" (Alves, 2018), para que el blanco pueda pensar la ciudad como un espacio seguro y "civilizado" precisa de construir cárceles urbanas que contengan aquello, y aquellos, que causa disrupción en su acomodada autopercepción. Por ello, entender la lucha gitana en los espacios urbanos racializados requiere pensar con honestidad y responsabilidad política la producción de guetos gitanos, su origen e intencionalidad, así como cuestionar esa "inocencia blanca" que se beneficia del antigitanismo de Estado. 


\section{MICHAEL JUAN SIERRA}

\section{Alumno da Escola de Arquitectura participante no obradoiro}

Sempre sospeitei que as políticas de integración fallaban nalgún punto, pero por propio descoñecemento, ou ben pola miña posición privilexiada na sociedade, padecín dunha falta de interese en profundar nos problemas dunha realidade á que non me enfronto no meu día a día. Nunca fun quen de comprender que era o que en realidade fallaba ou cal sería a alternativa ás políticas actuais.

Un pode pensar que as solucións aos problemas da integración poden estar na academia, pero, desgraciadamente, non hai maior cegueira que os privilexios dunha elite intelectual que se nega a afrontar o seu papel neste asunto.

Estas últimas semanas déronme que pensar sobre a violencia institucional e social á que se enfrontan as diferentes minorías sociais no seu día a día. Pensar en como os diversos colectivos son obxecto de políticas de "integración" ou inserción social, que están plantexadas dende as mesmas bases que producen a súa marxinalización e guetización. Como os propios individuos que plantexan e levan a cabo as políticas de integración, non fan máis que reproducir e perpetuar a desigualdade social imperante.

Tras escoitar diferentes opinións e experiencias persoais, das diferentes conclusións que puiden sacar, creo que a máis clara é que o futuro para reducir as desigualdades sociais, parte de asumir os privilexios cos que cada un conta. Está na nosa man axudar a reducir estes problemas, pero nun proceso liderado polos verdadeiramente afectados, no que se deixen de lado actitudes paternalistas e políticas asistencialistas, e todas as minorías teñan voz. 


\section{FERNANDO PÉREZ}

Alumno da Facultade de Historia do Arte participante no obradoiro

Autonomía, reparación e integración son as tres palabras que máis me bateron na cabeza durante este obradoiro.

A procura da autonomía non é outra cousa que a liberade para decidir sobre o propio ser, a se definir mais non a ser definido; autonomía que é, de seu, a loita contra o privilexio branco, masculino, heterosexual, urbano e capitalista que ordena e xerarquiza por debaixo de si mesmo todo aquilo que está fóra de si.

Reparación do dano causado por este privilexio, xa non por discutir se é posíbel facermos xustiza co pasado, cos que xa non están, senón para non reproducir as mesmas estruturas que o levan a perpetuar xa durante séculos; reparación que pasa polo recoñecemento dese mesmo dano, da estrutura e do privilexio mesmo.

E a integración, claro. Como se pode integrar alguén que non forma parte do discurso dun Estado-nación nese mesmo discurso? A mentira do Estado-nación exclúe, por definición, todo aquilo que cae fóra de si mesma: non é unha autonomía que suma máis liberdade, senón privilexio que quere só para si a liberdade de ser.

No diálogo entre grupos humanos nacen culturas que reúnen elementos daqueles, pero que tamén incorporan outros modos de facer diferentes. A idea da integración muda dunha cultura noutra é, logo, falaz: sen o diálogo, sen a tensión que xorde da convivencia, non podemos falar senón de asimilación; a idea da integración, ligada á existencia dun Outro que chega/nace a un Estado-nación, só se pode entender pola derrota dese Outro, dese inimigo, que acha o lugar que tiña xa predestinado: a cadea, a exclusión. Logo a integración, nos termos que hoxe manexamos, é imposíbel, xa que forma parte do mesmo monólogo da modernidade occidental. 
TIFFANY LÓPEZ GANET | Arquitecta e membro de Afrogalegas

\section{espazo e nosoutras}

O cartaz de Arquitecturas Ambulatorias atraeume xa de primeiras: unhas xornadas nas que se abordaban temas moi variados en torno á cidade e a súa poboación desde unha postura crítica e con múltiples voces. Antes de nada, agradezo a iniciativa e mando a miña noraboa polo traballo. Era necesario falar do que se falou: de como ocupamos o espazo, das desigualdades nesa ocupación, das estruturas de poder e dun intento de decolonizar o territorio. Pero tan importante ou máis era quen falaba e desde onde; o antixitanismo e o racismo desde a experiencia e a loita. Máis que solucións definitivas, das xornadas lévome máis dúbidas, preguntas que resolver e ideas a investigar. Hai temas que se repetiron e que me seguen roldando a cabeza, como esa idea de decolonización e deconstrución do poder e dunhas estruturas abstractas que acaban sendo tan necesarias como utópicas. Os equipos interdisciplinares redactores dos proxectos deben ser conscientes da súa responsabilidade e coñecedores de máis realidades que da súa. As metodoloxías participativas buscan dar voz á veciñanza afectada nun contexto moi pechado e concreto que non consegue resolver os problemas reais que levan a que esa parte da poboación non estea "integrada".

E aí o problema. Estas iniciativas buscan unha asimilación disfrazada de integración nas que se perpetúa a "outredade" cada vez que non se teñen en conta a lei de estranxeiría, o racismo cotián que tan ben describe Grada Kilomba e cada unha de nós, a colonización e toda a xerarquía de poder resultante. A diferenza racial coincide coa diferenza espacial. Pénsasenos desde esa diferenza que empobrece, inciviliza, infantiliza, erotiza e animaliza, seguindo as ideas da autora de Memórias da plantação. E desde ese paternalismo estanse a construír as burbullas protectoras e salvadoras. Esquecendo que ao saír desas burbullas, o problema continúa, que a "outredade" levámola nas costas.

Falo desde a miña posición como muller, negra, galega e arquitecta. Non podería nin sabería facelo doutra maneira. 


\section{ROI ZAS}

Alumno da Escola de Arquitectura participante no obradoiro

El cuerpo gitano representa una amenaza para el Estado y para el proyecto europeo blanco de modernidad científica. Esta imagen del gitano y de lo gitano se ha ido construyendo a lo largo de más de 500 años de represión, genocidio y expulsión hacia las periferias. Para el pueblo romaní, el hecho de seguir existiendo es resistir.

Sin ningún rimbombante proyecto teórico detrás alumbrado por la academia, si es que la academia alguna vez generó un proyecto emancipatorio con su pulido lenguaje, las formas de resistencia de las comunidades ubicadas en los márgenes del sistema mundo (capitalista, patriarcal y colonial) siguen vivas. Los ejemplos son múltiples y algunos recientes como la revolución de Rojava, pero también cercanos como el pueblo romaní con su modo de vida despreciado y perseguido históricamente. Sus prácticas de resistencia comunitarias basadas en redes de apoyo mutuo y de autogestión (con todas sus carencias), sobreviven en un contexto hostil porque funcionan y sirven para solucionar parcialmente desde el barrio los problemas concretos derivados de la segregación espacial.

En O Campanario, sin caer en la romantización del ghetto, la falta del servicio de limpieza municipal se gestiona entre las vecinas. La autoconstrucción incremental da respuesta a quienes quedan fuera del mercado del alquiler, el transporte compartido entre vecinos soluciona la ausencia del transporte público y la vigilancia informal de la comunidad cuida a las niñas y niños que juegan en la calle.

Estas son las herramientas disponibles para transformar y para generar lazos sin dinero de por medio, son tangibles, están alejadas de abstracciones ideológicas y el capitalismo lo sabe, ¿o es casualidad que el centro vecinal, el espacio con la mayor potencialidad para condensar sus reivindicaciones, esté cerrado? Los retos son muchísimos pero si se quiere construir un proyecto de emancipación desde la propia comunidad con una perspectiva decolonial, feminista y anticapitalista no veo otros medios más concretos y adaptables que los principios libertarios. 
CATHRYN TEASLEY | Docente en CC. da Educación (Invest. MOPS, GIE)

\section{Enfrontar o monstro}

As xornadas Arquitecturas Ambulatorias resultaron á vez innovadoras e imprescindíbeis, a faceta innovadora presente tanto no seu deseño interdisciplinario e intersectorial como nas súas mensaxes. 0 imprescindíbel residía na súa capacidade de dinamizar e abrir novas liñas de debate e mobilización en torno a un proceso de opresión local persistente. En efecto, este evento deu pé á reflexión crítica en polo menos tres planos analíticos:

Nun plano epistemolóxico, arroxou luz sobre os discursos hexemónicos de representación postos a circular polos medios de comunicación de masas e polas institucións públicas. É dicir, remitíanos a pensar, por exemplo, no que Shari Popen (2002: 387) denomina "tecnoloxías discursivas e simbólicas da contención", emitidas desde unha autoridade narrativa que filtra, distorsiona, limita e exclúe determinada información chave sobre realidades e acontecementos concretos protagonizados por colectivos subalternos, pois dita información é cualificada de "excesiva" ou de "inadecuada".

Nun plano ontolóxico, o xurdimento e duración prolongada no tempo da racialización, invisibilización, estigmatización e subordinación de colectivos, barrios e comunidades -como a veciñanza maioritariamente xitana-romaní do Campanario- fai lembrar as mensaxes do lúcido pensador e activista anti-racista e anti-colonial Frantz Fanon (1952; 1961), que denunciou os procesos de deshumanización impostos por unha dualidade colonial racista e supremacista baseada na simbólica zona do ser (correspondente aos colonos) e noutra zona do non-ser (correspondente aos colonizados).

Nos tempos actuais, nos que un colonialismo de facto -xa non de iure-campa ás súas anchas, o privilexio branco reside na zona do ser, mais a súa posicionalidade favorecida a miúdo fica estratexicamente invisibilizada, tamén, para protexela e mantela á vez que é erixida como "normal". As e os integrantes do grupo subordi- 
nado fican culpabilizados e responsabilizados polas súas circunstancias - o que William Ryan (1976) acuñou hai moitos anos como "culpabilizar á vítima“. Mais aquí non se trata de vitimizar; trátase de loitar contra este estado inxusto das cousas.

Isto lévanos a un derradeiro plano: o político. Volvendo á contención, atravesa as políticas urbanísticas tamén. Thomas Pedroni (2011) identifica un conxunto de políticas neoliberais de desenvolvemento (contra)urbanístico que funcionan para conter os barrios deprimidos, segregándoos de maneira indirecta doutras comunidades próximas. Ditas políticas maniféstanse a través dun espectro de posturas e medidas, desde o laissez-faire (de desinterese e neglixencia política) ata medidas de construción selectiva de infraestrutura.

Pechando este círculo de contención urbanística neoliberal, tamén aumentan as medidas para a elección de centros educativos, o cal adoita conducir á chamada fuga branca (Orelus, 2013) das familias privilexiadas que se queren afastar dos centros nos que se concentran os sectores máis racializados das poboacións estudantís.

Ante este panorama glocal de inxustizas múltiples, e á hora de formular respostas, as palabras dunha conferenciante de Arquitecturas Ambulatorias -Pastora Filigrana García, avogada e comentarista de ascendencia xitana-romaní- resultan esclarecedoras:

"El neoliberalismo imbrica varios dispositivos de explotación que se retroalimentan: el racismo, el colonialismo, el patriarcado y el capitalismo. Son varias cabezas de un mismo cuerpo monstruoso. La emancipación pasa sin duda por articular discursos y prácticas de lucha en todos los frentes, y para eso es esencial la atención a las diversas manifestaciones del monstruo". (Filigrana, 2018: 1) 


\section{ROSA FERNÁNDEZ}

\section{Alumna da ETS de Camiños (GIOP) participante no obradoiro}

Estas jornadas me han dado la oportunidad de descubrir una situación a la que era totalmente ajena en mi propia ciudad.

La situación de los habitantes de 0 Campanario es muy precaria pero, lo más preocupante, es que tienen el sentimiento de no tener derecho a quejarse o tienen miedo a hacerlo. En este barrio viven niños, personas mayores de 65 años e incluso algunas personas con enfermedades graves y en situación de total dependencia; carecen de aceras, farolas, contenedores y recogida de basura, transporte público... una serie de servicios básicos de los que disponemos en todos los demás barrios de la ciudad. El Ayuntamiento ha sido el que los ha puesto en esta situación para después abandonarlos.

Un ejemplo de este sentimiento lo vimos cuando realizamos una encuesta a los vecinos para conocer su historia y situación actual, muchos no quisieron contestar por miedo a que les pudiera perjudicar o les pudieran retirar alguna de las ayudas que reciben. Incluso, algunos que contestaron, diez minutos más tarde se arrepintieron y nos pidieron que rompiésemos la encuesta porque "no querían problemas".

Respecto al local vecinal, creo que es casi una provocación que lleve meses finalizada la reforma y permanezca cerrado. En 0 Campanario no hay bares, no hay tiendas, ni siquiera plazas dónde poder reunirse y pasar el tiempo en comunidad que, a estas alturas, es lo único que piden estas personas. Todos los coruñeses deberíamos sentirnos responsables de la situación de indefensión que viven en 0 Campanario y acompañarlos en la lucha por tener un barrio mejor, o por lo menos, digno. 


\section{CARLOS DIZ | Antropólogo e docente na Facultade de Socioloxía}

Corpo, verbo, acento, pel. Memoria, murmurios, identidade. Desexos, etnicidade. Viaxes e fronteiras. Medos. Diversidade. Nós estamos feitas de historias tanto como de pel e ósos, e as cidades tamén. Pensar a cidade máis alá do plano, facer arquitectura cos ouvidos, sentindo o que conta e o que cala un barrio. Somos o que contamos e o que non contamos, e as cidades tamén.

Dende hai miles de anos as cidades fóronse construíndo á imaxe dos corpos, ou mellor, do corpo, dun corpo (en) singular. Non é casualidade que os romanos, ao fundaren unha cidade, establecesen un eixe central ao que chamaban umbilicus, o embigo. A Modernidade europea, por definición urbanocéntrica, racista e patriarcal, fixo desta triangulación (cidade/metrópole, "raza branca" [ou a súa ficción] e patriarcado) un vector moral -e tamén xeopolítico, económico e ecolóxico- no que sustentar as súas ideas de "orde", "civilización" e "progreso". Este vector funcionou tamén nas cidades... e segue funcionando. Aquel corpo-imaxe da cidade era e segue sendo branco, capaz, independente, varón, proporcionado, áxil e motorizado. 0 resto de corpos, que latexan mundos dentro deles, son pensados como amezas: perigosos, asimilables,sucios e periféricos.

Arquitecturas Ambulatorias permitiu deambular os sentidos e desprazar a mirada, poñendo estes corpos no centro, cos seus dilemas, a súa cor e os seus afectos. Fixo que distintas realidades urbanas -a d'O Campanario, na Coruña, mais tamén outras en lugares varios- se revelasen e rebelasen a un tempo, coa súa propia voz e co seu acento, demostrando que non hai arquitectura sen sociedade nin cidade sen diversidade. Aprendemos entre corpos distintos e en cidades distintas - jaínda que vivamos na mesma!- que o corpo e a comunidade son a primeira arquitectura, e que hai que coidalos e respectalos na súa diferencia. Porque somos o que facemos coa nosa diferencia, e as cidades tamén. 


\section{SIMÓN RODRÍGUEZ}

Alumno da Facultade de Socioloxía participante no obradoiro

Persoalmente este obradoiro serviume para aprender e coñecer numerosas perspectivas de investigación a hora do traballo de campo, a aprender máis da historia urbana de Coruña e as formas que se usaron para oprimir a os sectores pobres da cidade, saber máis da historia da etnia xitana e aprender a traballar estas temáticas en grupo.

Pese a que a existencia de barrios moi degradados é coñecida en case todas as cidades, sorprendeume a historia de loita social deste, especialmente a súa loita tan efectiva contra a aparición do tráfico, e como despois de ter avanzado en certos servizos se puido volver a retroceder pechando indeterminadamente o centro cultural, quitando a limpeza urbana e ameazando con construír neses terreos.

Pese a ter diferenzas notables o que contan coa construtora lémbrame en certa maneira a como agora mesmo se está destruíndo en Vigo o barrio do Cura a través dunha construtora e non se lles está pagando as indemnizacións ós veciños por considerar que vivían en infravivendas.

Fíxome reflexionar o feito de descubrir os condicionantes da RISGA e como un traballador social pode ir a unha casa do barrio do Campanario e dicir que está ben cando, a pouco que preguntabas, xa che dicían varios problemas que tiñan.

Por último, quédome con unha das frases das charlas "quen non ten unha vivenda non é un cidadán, é un supervivente“, no barrio do Campanario por agora teñen vivenda, pero viven nun medo constante de perdela. Como se dixo no último faladoiro se se promulgase o benestar no barrio toda Coruña sairía gañando, por iso penso q se lles debe de tratar coma calquera outra zona da cidade. 


\section{PLÁCIDO LIZANCOS | Docente na ETS de Arquitectura}

\section{buen vivir, para todos y todas}

Han pasado 51 años desde el momento en que se enunciara por vez primera el concepto de derecho a la ciudad.

En 1968, Lefevbre nos explicaba alarmado que la ciudad se había convertido en una mercancía, que por diversos subterfugios se le expropiaba a sus verdaderos propietarios: la ciudadanía. Nos advertía que esa construcción colectiva a la que todas las gentes tienen derecho -el derecho a la ciudad- debía ser defendida pues con aquel derecho las personas nos construimos como tal.

En el más de medio siglo que ha transcurrido desde entonces la situación no ha hecho más que agudizarse, alcanzando prácticamente cualquier rincón del planeta, dando lugar a todo tipo de estrategias urbanísticas que disfrazan el inmenso hurto. Rehabilitación, reforma interior, saneamiento urbano, mejora barrial, slum upgrading, recualificación ambiental o humanización son algunos de los camuflajes que en un número insoportable de casos han tomado las prácticas urbanísticas neoliberales.

El verdadero rostro de todo aquello son los procesos de expulsión de los residentes tradicionales de los barrios, la substitución de las actividades cotidianas por otras de alto valor añadido, la turistificación, la Disneyficación o la gentrificación.

La ciudad tradicional no dejaba a nadie atrás. Tenderos, albañiles, policías, jubilados y jubiladas, enfermos, ricos y pobres se necesitaban los unos a los otros para desarrollar sus proyectos vitales, repartiéndose consensuadamente las cargas y también los beneficios que implicaba vivir colectivamente.

Ahora la ciudad capitalista de la economía global, una ciudad que construyen codiciosos actores sin cara, sostiene su negocio en la creación de desigualdad. Y para esto ha transformado a la "ciudadanía" en "clientela". Y en esa nueva clase urbana no están todas 
las personas. Las familias monomarentales, los inmigrantes, las minorías étnicas, los refugiados, los desempleados o las personas mayores con baja capacidad de compra no son consideradas por el "mercado". Por eso se les desplaza a los márgenes, en una batalla que ocasiona dolor y muchas bajas.

o Campanario es uno de los frentes de esta batalla. De la batalla de un sistema voraz que tiene apetito por este lugar. Pero es también el campo de batalla de quienes reivindicamos que la gente vuelva a ser dueña de la ciudad donde la posibilidad del "buen vivir" se le ofrezca a todos y a todas. 
El local vecinal daba mucha vida aquí, los chavales hacían sus deberes o tenían actividades en él, los mayores jugaban al tute y pasaban el rato, había clases de costura... Y teníamos el culto, en la planta de abajo. Desde que dijeron que lo iban a rehabilitar, está cerrado. Yo creo que no lo quieren abrir. Si quisieran lo harían, es suyo, no tienen más que venir y hacerlo. Pero ahí está, una cantidad de millones que se han gastado en arreglar un edificio que no estaba tan mal. Quizás hubiera sido mejor destinar ese dinero a arreglar cosas más importantes que hacen falta en el barrio. Y ahora está cerrado, fue una trampa.

Nos quieren echar de aquí y ya empiezan a hacerlo, los vecinos están preocupados, la gente está inquieta porque si no nos quieren aquí, se acabó para nosotros.

-Veciño do barrio do Campanario. 


\section{ÍNDICE DE FOTOGRAFÍAS}

p. 9: Sinal vial na estrada dos Fortes, San Pedro de Visma, A Coruña. Fonte: Cristina Botana.

p. 11: Ortofoto do litoral noroeste coruñés tratada a partir da imaxe de Google Earth.

p. 12: Voo americano, 1957. Fonte: Fototeca dixital do CNIG.

p. 13: Voo nacional, 1986. Fonte: Fototeca dixital do CNIG.

p. 14: Voo quinquenal, 2002. Fonte: Fototeca dixital do CNIG.

p. 15: Voo PNOA, 2010. Fonte: Fototeca dixital do CNIG.

p. 19: De arriba abaixo. Fotografía do barrio de O Portiño dende o Parque de Bens. Fonte: Cristina Botana.

Fotografía tirada durante o roteiro polo barrio do Campanario, O Portiño, San Pedro de Visma e a súa contorna. Fonte: Cristina Botana

p. 23: Final do Obradoiro de autoconstrución no Portiño, 2010. Fonte: Desescribir.

p. 25: De arriba abaixo. Veciñanza do Campanario. Fonte: Veciñanza do Campanario. Recompilada polo colectivo Infradomus.

Construción das primeiras vivendas do Padre Villa. Fonte: Un sueño hecho realidad. La vida y obra del Padre Villa, 25 años. Caixa Galicia.

Veciñanza do Campanario. Fonte: Veciñanza do Campanario. Recompilada polo colectivo Infradomus.

p. 26: De arriba abaixo. Clube de fútbol xuvenil do barrio. Fonte: Veciñanza do Campanario. Recompilada polo colectivo Infradomus.

Derrubamento do vertedoiro de Bens. Fonte: César Quián. La Voz de Galicia, 1996.

Proxecto de rehabilitación presentado pola AAVV O Campanario e Infradomus. Fonte: Infradomus.

Homenaxe ao Padre Villa, 2001. Fonte: Veciñanza do Campanario. Recompilada polo colectivo Infradomus.

p. 27: De arriba abaixo. Imaxe do obradoiro de autoconstrución, 2010. Fonte: Desescribir.

Manifestacións polo dereito a traballar, 2015. Fonte: Patricia G. Fraga, EI Ideal Gallego, 2015. 

